\title{
BIOFUEL DEVELOPMENT IN GHANA: POLICIES OF EXPANSION AND DRIVERS OF FAILURE IN THE JATROPHA SECTOR
}

\author{
Abubakari Ahmed ${ }^{1}$, Benjamin Betey Campion², Alexandros Gasparatos ${ }^{3}$ \\ ${ }^{1}$ Graduate Program in Sustainability Science - Global Leadership Initiative The University of Tokyo, 5-1-5 \\ Kashiwanoha, Kashiwa City, Japan. \\ ${ }^{2}$ Faculty of Renewable Natural Resources, Kwame Nkrumah University of Science and Technology, PMB, \\ Kumasi, Ghana. \\ 3Integrated Research System for Sustainability Science (IR3S), The University of Tokyo, 7-3-1 Hongo, \\ Bunkyo-ku, Tokyo 113-8654, Japan.
}

\begin{abstract}
Biofuel development was mainly promoted in several parts of Africa as an energy security or rural development strategy. Jatropha was the biofuel feedstock that received the most interest across Africa from investors. However, jatropha expansion gave rise to a number of contested issues, which produced conflicts, winners, and losers. Access to land was at the heart of several of these conflicts. Though some success stories of individual jatropha projects have been documented, the overwhelming majority of these projects in Africa have either collapsed or faced significant difficulties. Understanding the reasons behind the failure of the jatropha sector is an important gap in the academic literature, while the lessons learnt from failed projects could inform future policies and practices. This literature review synthesizes the key drivers of failure of the jatropha sector in Ghana as identified in the literature, and complemented through site visits and expert interviews. It identifies a number of reasons behind the failure of individual jatropha projects such as poor business planning, institutional barriers, limited community participation, unfair compensation practices, obstacles posed by civil society and unconstructive involvement of chiefs. The findings indicate the systemic nature of these problems as they often worked synergistically to catalyse the collapse of many jatropha projects in Ghana. Re-vitalising the biofuel, and especially the jatropha, industry is virtually impossible given the current challenges. This would require a renewed political interest in Ghana particularly to deal with the deficits of the land administration institutions.
\end{abstract}

Keywords: Biofuels, energy security, Jatropha, rural development, project collapse, Ghana 


\section{INTRODUCTION}

Local energy demand in most countries of Sub-Saharan Africa (SSA) is largely met through locally sourced biomass energy (e.g. fuelwood, charcoal) or imported fossil fuels [1][2]. At the same time, a large part of the population lives under extreme poverty without access to modern fuels. This lack of access to modern fuels has been considered both a consequence and a driver of poverty [3]. Therefore, policy targets such as energy security, economic development and poverty alleviation are often highly interlinked in SSA [4][5].

Despite some early efforts in the 1980s [6][7], liquid biofuels largely emerged in the last $10-15$ years as a potentially promising strategy to meet these interconnected policy objectives in SSA [6][7]. Following the adoption of ambitious biofuel policies in Brazil, EU and the US ${ }^{1}$, biofuels gained a lot of international attention, including from African governments, increasingly becoming an attractive sector for foreign direct investments (FDIs) in the continent [8][9][10].

In SSA, rural development and energy security seem to have been by far the most important drivers for biofuel expansion with climate change mitigation playing a negligible role - if at all [7][11]. The emphasis in several African countries on FDIs in the agriculture sector as a pathway to economic development (and as a response to limited state-led investment) resulted in the sharp increase in the number of biofuel projects (especially jatropha-related) and the scale of related land acquisitions across the continent [12][13][14][15][16].

The hope that biofuels could promote energy security and rural development was, however, contested given the regional differences and relationality in the drivers for biofuel development [7][17]. What shed

1 The global biofuel boom of the 2000s was the result of a set of interconnected international circumstances. The main drivers of biofuel expansion varied between countries, but were mostly associated with energy security, economic gains (including rural development and foreign exchange savings) and GHG emission reductions [7][28][29][30][31][32][33][34][35]. 
further doubt on the perceived benefits of biofuels was the eventual emergence of negative impacts at the local level, including some highly contested issues such as food security [8][12][18][19][20][21] and land grabbing [22][23][24] which have produced conflicts, winners and losers [25][26][27].

While some jatropha success stories have been documented in SSA [36][37][38], the bulk of jatropha projects have underperformed or totally collapsed in Eastern and Southern Africa [37][38][39][40][41]. However, comprehensive studies in West Africa that explore the reasons and evidence for the failure of biofuel initiatives are still limited. This remains an important gap in the academic literature considering three main reasons. Firstly, there is a long history of formal policy interest in biofuels in West Africa, following the adoptions of energy protocol to boost energy supply in the sub-region by the Economic Community of West African States (ECOWAS) [52]. Secondly, while numerous policy directives have been put in place between 2006-2008 that promoted biofuels as a rural development strategy in the region [42][43][44][45][46][47] ", the actual progress in implementing these mandates has been unclear [57]. Thirdly, the policy support of several West African governments to attract FDIs in the biofuel sector (as manifested by the surge of largescale land acquisitions for biofuels) has raised many concerns [2][9][10][48][49].

The aim of this literature review is to re-construct the evolution of biofuel policies in Ghana and identify the reasons for the critical failure of the jatropha sector. Given the on-going discussion on whether jatropha could still be a viable development option for Africa [36][38][50][51], the outcomes of this paper will provide significant evidence from Ghana that could be considered in the formulation of national plans if jatropharelated development is to be re-kindled.

The review starts by offering an overview of the main policies and actors involved in the biofuel sector in Ghana (Section 2). Section 3 records the main smallholder-based (Section 3.1) and large-scale (Section 3.2) biofuel projects implemented in Ghana in the last decade, while Section 4 reviews some of their key environmental and socioeconomic impacts. Section 5 discusses the main reasons for the widespread collapse of jatropha projects such as the discovery of crude oil (Section 5.1), the role of civil society (Section 5.2) and chieftaincy institutions (Section 5.3), the unfulfilled utopian promises made by biofuel investors (Section 5.4), the institutional barriers posed by the national government (Section 5.5), and the limited participation of local communities in project design and implementation (Section 5.6). Section 6 puts

2 West African countries have adopted different blending mandates at different stages; e.g. Ghana (B20 by 2030), Nigeria (E10 by 2020), Mali (E20 by 2023), [53][54][55]. Furthermore, the ECOWAS has set a regional target of E15 by 2030 for its member states [56].. 
these findings into perspective by developing a conceptual framework of the linkages between these drivers of failure and the main actors involved. It further identifies some of the main lessons learnt from failed jatropha projects that could inform future biofuel practices in Ghana and beyond.

\section{THE EVOLUTION AND DEVELOPMENT OF BIOFUELS IN GHANA}

\subsection{Evolution of biofuel policies and their drivers}

The genesis of biofuel interest in Ghana can be traced to Onua Amoah, a bio-chemist and Chief Executive Officer of Anuanom Industries Ltd [12]. In 2003, he called for government support to promote the development of jatropha biodiesel, including the training of farmers in jatropha cultivation [12][58]. Following his successful demonstration of biodiesel production from jatropha, the government of Ghana established four committees to offer recommendations regarding the promotion of biofuels nationally [58]. These committees were set under the new mandate for meeting the renewable energy targets following the adoption of ECOWAS Energy Policy in 2003 [53].

After a series of meetings, the first draft biofuel policy was issued in 2005 . It recommended a $20 \%$ biodiesel blend (B20) for all government vehicles and the establishment of a Biofuel Implementation Group (BIG) under the Energy Commission [58]. In 2006, the National Jatropha Planning Committee submitted a revised version of this biofuel policy to the government for consideration. This revised version contained ambitious targets of 5\% gasohol (E5) by 2010 and 10\% biodiesel (B10) by 2015 in transport fuel used by the government. These blends where to be mainly met through the expansion of jatropha (for biodiesel) and cassava/sugarcane (for bioethanol) [59].

In 2006, the Strategic National Energy Plan (SNEP) included a refined policy statement and new biofuel blending targets for both gasoline and biodiesel. The policy objective was to "secure and increase future energy security by diversifying sources of supply through fuel substitution and complementation of alternative fuels so as to achieve 10 percent penetration in supply mix by 2015 and 20 percent by 2020" [53] (page 104). 
3 While jatropha is toxic and unsuitable for human consumption, hence not a food crop per se, in reality it can divert indirectly food production through competition for land, water, capital and other agricultural inputs [7]. 4 EU-RED enforced an ambitious blending mandate of $20 \%$ by 2020 , and allowed feedstock/biofuel imports from outside the EU if the blending mandate could not have been met through domestic production [65]. 
relief to biofuel companies). These policy directives imply that more FDIs and larger land acquisitions would have been necessary to meet these targets [42][60].

The ensuing Renewable Energy Act of 2011 (Act 832) aimed to further boost biofuel development. The Act specifies the required steps for biofuel production in Ghana, but very limited prescriptions are made about the formal processes to be followed during large-scale land acquisitions for feedstock production [12][66][67]. Figure 1 highlights the different stages and required submission procedures for issuing a biofuel development license, but whether these steps were actually followed is another matter. Feedstock production licenses (either for small-, medium- or large-scale production) are set to run for a maximum of 20 years, while biofuel export licenses for 5 years [66]. Apart from the requirement to disclose a business plan (technical, financial, social and environmental feasibility analysis), there is no document that is directly linked to rural development.

\section{[Figure 1]}

However, since 2007, there has not been any actual implementation of the adopted biofuel policy initiatives (Table 1). Due to this lack of policy implementation there is currently no commercial domestic biodiesel production or use in Ghana [68]. Crude oil discovery and low political commitment are key reasons for this lack of implementation [12][Personal communication, Energy Commission], but the reasons of actual jatropha project failure are much more multi-faceted and discussed extensively in Section 4.

\section{[Table 1]}

To boost feedstock choices, a sugarcane policy was drafted and underwent wider stakeholder consultation in 2015-2016. Among other things, ethanol was mentioned in the sugarcane policy but not explicitly in the context of transport fuels [69]. Yet if sugarcane production is boosted then it might contribute to meeting the existing ethanol blending mandates.

The above suggest that the drivers of biofuel/feedstock development in Ghana appear to have shifted in the past 12 years. While, some scholars often cite rural development as the main initial driver of biofuel development in Ghana [42][70][71][72] given the subsequent dominance of FDIs in the Ghanaian biofuel sector, the state-led initiative is often over-shadowed in biofuel discourse and literature. However the fact 
that the state-led initiative targeted government vehicles implies that energy security was the primary driver [53](page 55 \& 104), with rural development being a secondary focus. Policies after the collapse of the state-led initiative (2007-2008), and particularly the incentives for FDls and the adoption of an exportoriented model, aligned biofuel development in Ghana more closely with rural development objectives.

\subsection{Main biofuel actors in Ghana}

The capability of existing institutional frameworks in African states to regulate large-scale land acquisitions and biofuel development has been questioned [8][26]. At the onset of the biofuel boom in the early-to-mid 2000s most African states (if not all), including Ghana, did not have legal frameworks in place to regulate the biofuel sector, including biofuel-related large-scale land acquisitions [6][8][26]. In Ghana, past attempts to create a new ministry and resolve the institutional crisis in the energy sector (e.g. the stabilisation of fuel prices, improvement of fuel supply and fostering partnership with the African Gas Pipeline Company) have largely failed [64][67].

In 2014, in the wake of the unprecedented energy crisis the government of Ghana created a Ministry of Power, out of the existing Ministry of Energy and Petroleum (MoEP). Biofuel issues are still under the Ministry of Energy and Petroleum (MoEP), with the Energy Commission, the Ministry of Food and Agriculture (MoFA) and the Environmental Protection Agency (EPA) being responsible for all upstream activities of the sector (Table 2). All regulatory issues and downstream activities such as the licensing of refineries and distributors fall under the mandate of the National Petroleum Authority [64][67].

\section{[Table 2]}

While the Energy Commission stipulated the role of major stakeholders in the biofuel sector (Table 2), their interrelationship and interactions is not always clear and well documented in the literature. Most of what is currently known for Ghana relates to local agreements between companies and local communities [73]. Figure 2 maps the lines of influence between key stakeholders in the Ghanaian biofuel sector, and creates an institutional landscape showing their interrelations. Considering the large number of involved actors (and their different agendas and vested interests, Section 5), their actual interactions are rather complex but largely fall fall within four categories, (a) provision of funding, (b) formulation of policies, (c) implementation of policies, and (d) Research and Development (R\&D) (Figure 2).

[Figure 2] 
Figure 2 suggests that a central stakeholder at the national level is the Biofuel Implementation Group (BIG) that has been established to coordinate all biofuel activities in Ghana. The different ministries are generally responsible for influencing policy formulation with donor assistance through multilateral and bilateral cooperation. The various agencies under the ministries are responsible for the implementation of policy directives (Table 1), including the licensing of biofuel companies. Issues related to land acquisitions and registrations fall under the mandate of Lands Commission and Town Planning. R\&D is largely undertaken by tertiary educational institutions and government research agencies, with funding usually coming from both bilateral and domestic sources (Figure 2). Funding to implement biofuel projects mostly comes from the private sector through FDls and to some extent from bilateral research agreements.

At the local level, grassroots institutions such as traditional authorities, Non-Governmental Organisations (NGOs), farmer organisations/associations, and trade unions interact with biofuel investors following their different vested interests (Section 5), supposedly through the confines of national policies (Figure 1, Table 1).

\section{BIOFUEL PROJECTS IN GHANA}

\subsection{Smallholder projects}

In 2003, the state-led National Jatropha Project was initiated through the pioneering work of Anuanom Industries (Section 2.1). The aim was to establish $1,000,000$ ha of jatropha plantations across 53 districts through both small- and large-scale feedstock production, including significant plans to integrate outgrowers. Under this scheme, the state was to provide seedlings and extension support to smallholder farmers. After harvesting, the state was to buy the jatropha seeds from the smallholders, produce biodiesel with help from Anuanom Industries Ltd., and use it to run state vehicles (Section 2.1). This process was at the stage of distributing seedlings to farmers when the jatropha pioneer (Onua Amoah) died in 2007. The initiative was basically abandoned after a change of government in 2008 and the new focus of exporting feedstock/biofuels that culminated in the 2010 bioenergy policy (Section 2.1).

Parallel to this, in 2004 small-scale jatropha projects were initiated in Dormaa and West Mamprusi Districts by the Kumasi Institute of Technology and Environment (KITE) and the GRATIS Foundation [61][74]. The small-scale project in the Yaakrom community (Dormaa District) entailed a Rural Enterprise project and a 


\subsection{Large-scale projects}

After the decline of the early smallholder initiatives (Section 3.1), large-scale plantations, often funded through FDls, became the dominant mode of feedstock production in Ghana (Section 2.1). Previous studies that documented biofuel projects and large-scale land acquisitions in Ghana have reported mixed figures about the total number of companies, projects, and amount of land allocated [14][75][76][77][78][79][80].

For example, estimates range from 17 companies leasing 1.075 million ha [79], to 20 companies leasing 1.184 million ha [14], 36 companies leasing over 2,000 ha each for a total of 2.05 million ha [16] and 45 projects on 2.066 million ha of land [13]. Other sources have reported eight biofuel-related large-scale

5 For more information refer to: http://www.ghajaproject.net/index.html 
acquisitions in Ghana for a total amount of 132,000 ha [81]. These differences in number of companies involved and land acquired are largely due to the fact that these studies were conducted at different times. Furthermore, some of these studies offer aggregate numbers for all land-based agriculture investments, without disaggregating by crop or purpose (e.g. food, fibre, biofuel). It should be mentioned that some estimates such as those of Land Matrix have been criticized for not being able to distinguish between verified, unverified, failed, on-going, completed or even planned deals [13][48].

Another reason for these discrepancies is due to the difficulty in quantifying large-scale acquisition because the government of Ghana has not made easily available such data particularly due to them being scattered as a result of the decentralization of land administration [13]. In Ghana, most biofuel projects are tied to traditional authorities that do not often keep correct records of such locally- and politically-sensitive investments. Whereas the quality of reported cases in scientific literature is left to personal judgment [48][49], data users are faced with the non-trivial challenge of improving data accuracy before use.

Below, we address these limitations to the extent possible by updating an inventory of biofuel projects undertaken in 2012 by ActionAid Ghana by using some findings reported in the literature [10][12][14][72][75][76][77][78]. We supplement the published evidence with information collected by the authors through visits in local land registries in eight regions of Ghana and interviews with 20 experts throughout Ghana (September 2015) that reflect the main actors in biofuel value chains as identified in Section 2.2. Apart from simply reporting the characteristics of the land acquisitions themselves, we attempt to identify the eventual fate of each project, as well as the reasons that might have contributed to their collapse (Table 3).

\section{[Table 3]}

Our findings suggest that over 31 biofuel-related large-scale land deals were made between 2001-2011, comprising of 15 verified foreign and two Ghanaian companies. Foreign companies are mostly from Europe with fewer from Asia, America, and other parts of Africa. The size of each acquisition ranged widely from 202 ha for jatropha production by Savanna Black Farming and Farm Mgt Ltd, to 400,000 ha for oil palm and sugarcane production in the Afram Plains by the Indian Viram Plantation Ltd.

Whereas several studies report that the biofuel boom in Ghana was in 2006 [14], our review shows that the peak was in 2007, two year after the drafting of the first biofuel policy (Section 2.1). However, the first land acquisition related to biofuels was made as early as 2001 in Dipale-Gushie-Tunayilli of Northern Region, 


\section{BIOFUEL IMPACTS IN GHANA}

6 Section 5 discusses how some of these companies change their names as part of their strategy to remain in business. 
Studies about the impacts of biofuel projects in Ghana (overwhelmingly jatropha) have generated mixed findings. Whereas there is a strong evidence base (and sometimes consensus) for some impact categories, for others there is still a lack of strong empirical evidence (Table 4). It should be mentioned that all of the impact studies discussed below are limited to jatropha. Impacts studies for other feedstocks such as sugarcane and oil palm are not from the biofuel perspective.

\section{[Table 4]}

In terms of environmental impacts, a number of studies have reported the negative effects of jatropha projects to access to non-timber forest projects (NTFPs) such as medicinal plants, wild fruits, fuel wood and bush meat [14][23][89][91]. This is usually a result of the large direct and indirect land use change effects associated with the conversion of natural and semi-natural habitats to jatropha plantations [32][51]. Some perception-based studies have reported reduced water availability [89] and direct deforestation [88]. Other studies have addressed impacts on land use change [12][13], and changes in carbon stocks and associated carbon debts [94]. The findings of these studies are generally negative suggesting that the large-scale conversion of natural and semi-natural habitats to jatropha comes with significant environmental burdens [23][76][79][88][91][94]. Evidence for impact categories such as soil, water quality, and biodiversity loss is still limited and comes mainly from the Environmental Impact Assessment (EIA) reports of the projects [95][96][97].

When it comes to economic impacts, there are mixed results in terms of positive and negative effects. Positive effects are generally associated with income/employment generation while negative effects are related to the loss of traditional/customary livelihoods at the community level [14][23][79][88][91]. Interestingly studies have suggested that while the positive effects of jatropha projects are limited in terms of the absolute amount of jobs generated and income received, their stability is sometimes highly valued by the local communities [14]. Beyond the local community level, jatropha projects have been identified as an important source of FDls that could have had ripple positive effects on national economic development if the sector remained economically viable [79].

For social impacts, studies have observed effects on food security, land dispossession, community conflicts, and reduced trust of chieftaincy institutions [14][23][79][88][85][98][91]. However, there have also been reported a few instances where biofuel projects provided social services such as community development funds, schools and water projects through corporate social responsibility (CSR) avenues [89]. 
It is interesting to note that depending on the location of biofuel projects, different impacts are usually studied (Section 6.2). For example for projects located in the rainforest zone, environmental impacts such as deforestation and land degradation are the key focus [14][16]. On the contrary, impact studies for projects located in the savanna zone mainly revolve around food security and rural livelihoods [12][76][84]?

\section{DRIVERS OF JATROPHA PROJECT COLLAPSE IN GHANA}

\subsection{Discovery of crude oil}

In 2008, crude oil was discovered in commercial quantities off the Ghanaian coastline. This discovery coincided with the development and adoption of the SNEP, which included the national targets and priorities for biofuel development (Section 2.1). A number of studies have hinted that the discovery of crude oil significantly reduced political interest in the promotion of biofuels in Ghana, providing evidence that most of the biofuel activities outlined in SNEP were never implemented following oil discovery [12][42][68].

While none of these studies could directly attribute the abandonment/failure of specific jatropha project to oil discovery, there is some evidence to suggest the existence of a causal link. For example, in 2008, ScanFuel, a Norwegian company, acquired a large tract of land (allegedly 47,000 ha engulfing 16 communities) in Agogo for jatropha cultivation to supply the domestic fuel market (Table 3). While jatropha cultivation started in 2009 with the initial conversion of 350 ha, the focus of the project immediately shifted from large-scale jatropha to maize production (Section 3.2). This coincided with the period when Ghana took major steps in oil exploration, giving market signals that biofuels might become unprofitable in the short-term [82].

In another case, the farm manager of Jatropha Africa in Kadelso attributed the collapse of the project to the discovery of crude oil that presumably affected the motivation of investors (Personal communication, Farm Manager of Jatropha Africa). In fact, crude oil discovery might not only have affected domestic and foreign biofuel-related investments (e.g. oil palm and jatropha), but possibly had a wider effect for investment in the agriculture sector as a whole [99].

7 This is not unexpected considering that in the savanna zone of Ghana there is the paradox of over $80 \%$ of the total population being involved in agriculture, yet one in five persons being food insecure and one in nine children dying of malnutrition before the age of five [98]. 


\subsection{Civil society opposition}

Civil society has played a vocal role from the onset of the biofuel debate in Africa. Some NonGovernmental Organisations (NGOs) have promoted biofuel initiatives (usually smallholder-based) offering resources, knowledge and, often, "political" support [100]. Yet, possibly the majority of NGOs have been alarmed by the potentially negative socioeconomic and environmental impacts of biofuel expansion, particularly associated with large-scale feedstock plantations. Food security, loss of land tenure and livelihoods, and human rights violations were key issues that mobilized NGOs against large-scale biofuel expansion in SSA [83][101][102][103][104].

The belief that biofuels will take food out of the mouths of hungry people or steal their land has brought an ethically powerful argument against the entire spectrum of biofuel technologies [105][106][107] $]^{8}$. These have often been framed by NGOs in the rather catchy narratives of "food vs fuel" and "land-grabbing" [83][101][102][103][104].

While in reality the debate about the impact of biofuels on food security and access to land are very complex [108], the power of simplistic advocacy messages to mobilise resources and local communities against biofuel projects is undeniable.

An interesting example in Ghana is BioFuel Africa, a jatropha project in the Kusawgu Traditional Area (Alipe community) (Table 3). The Regional Advisory and Information Network Systems (RAINS), an NGO, captured this as the "story of how a Norwegian biofuel company took advantage of Africa's traditional system of communal land ownership, current climate and economic pressure to claim and deforest large tracts of land..... using methods that hark back to the darkest days of colonialism, this investor claimed legal ownership of lands by "deceiving" an illiterate chief to sign away 38,000 hectares with his thumb print.....We need a more aggressive campaign to halt land grabbing. ..... Those of us involved in this struggle want to tell the story as a warning to other African communities, leaders and policy-makers to be wary of the promises made by biofuel investors and the disasters that their land grabbing may bring" [84](page $1 \& 6)$.

The above passages echo concerns of neo-colonialism. The quotation also presents a "dead end" situation in the use of negative words to describe the situation, with the ultimate aim to raise concerns in the local

8 Other scholars even see biofuel development as a paradox or green-washing: "power and profit painted green" [27][109]. 
communities and mobilize them to stop the project. This negative publicity was later picked up by ActionAid Ghana [83], and eventually it incited radicalism among the Kusawgu youth to stop the project at all costs.

In its campaign message, RAINS also claimed that halting the project will be in the interest of rural communities in Northern Regions, and called for the deconstruction of the project citing the Local Government Act 1993, Act 462 and the Environmental Assessment Regulations LI 1652 that Biofuel Africa Ltd failed to comply with. Eventually RAINS and ActionAid Ghana successfully halted the BioFuel Africa jatropha project in Kusawgu [23][78][107] $]^{9}$, making the company to seek land in Kpachaa (Section 5.3-5.4).

While it is difficult to assess the legitimacy of the claims of RAINS and ActionAid as there is no conclusive empirical research on the topic, it is noteworthy in this case to see how NGOs used crisis narratives to gain support for environmental activism [23][77][78]. This capitalized on bad publicity about jatropha in other parts of SSA, which has been identified as a major source of failure for jatropha projects [13][80].

Civil society opposition can be a particularly difficult obstacle to overcome, especially considering that several biofuel projects have been "sold" as ethical investments to their international investors [38]. This is in a way a situation where differences in values lead to contestation and conflict, and eventually to crisis when the necessary social support is not mobilized [31].

\subsection{Unconstructive involvement of chieftaincy institutions and local elites}

Chieftaincy institutions are particularly strong in some parts of Ghana, holding significant power over land deals as they are custodians of $78 \%$ of land in the country [75][85][110][111][112]. There is evidence to suggest that chieftaincy institutions and local political elites played a key role in the collapse of some jatropha ventures in Ghana. In fact, the chieftaincy institutions have been described as "causers and arbitrators of conflicts in Industrial Jatropha Investments" in Ghana [85](page 6332).

Chiefs can catalyse conflict in such projects because through unclear ownership of land, illegal sale of land, unfair sharing of benefits, weak leadership and abuse of authority. A recent empirical study found that when chiefs' motivation in land deals matches up with expressions of goodwill and protection of local identity and citizenship, then land rights are protected [76]. However, this is not always the case especially when weak

9 Interestingly, some local community members that had hopes of improving their livelihood from the project by giving out their farmland, probably became worse off due to the project failure [23][77][78]. 
institutional frameworks and 'self-interested' chiefs are combined. Such an example has been the collapse of the Biofuel Africa jatropha project in Kpachaa in northern Ghana [73].

The "vilification" of BioFuel Africa investors from civil society (Section 5.2) is just one side of the coin when trying to understand the collapse of the company's projects. The illicit activities of chiefs also contributed to the abandonment of the company's 40,500 ha jatropha project at Yendi (Table 3, Section 5.2). In this particular case, the land transaction was presided by the chief on behalf of his people. Initially the chief sold already allocated land to the company [76] (double sale of land is a common practice in Ghana) [113]. However, the affected farmers did not know about this transaction up until Biofuel Africa started land clearing to plant jatropha. As a result, there was deep scepticism about the leadership and benevolence of the chieftaincy institutions in the Kusawgu Traditional Are ${ }^{10}$ [82][83]. The affected people staged numerous agitations due to land rights dispossession as there was no disclosure of the terms of the contract (or even the compensation clauses) between the chief and Biofuel Africa. A group of concerned farmers took the case to court, which ruled in their favour with Biofuel Africa Ltd eventually being compelled to abandon the project.

A second case is the 30,000 ha land acquisition by Kimminic Estates Limited for jatropha production in Atebubu (Table 3). In this case the traditional authorities could not tell the amount of land given to the investors, or even mention the specific names of the companies since most of the time they referred to all of them as the "jatropha people" [82].

In both of the above cases, the chieftaincy institutions catalysed the collapse (or halt) of the jatropha project. In the first case (BioFuel Africa, Yendi), the negative role played by chieftaincy had to do with the unfair sharing of benefits, weak leadership, and abuse of authority. The absence of regulators (intermediaries, observers, and even formal promoters) is common to such land acquisition processes, and can expose it to iniquitous and exploitative conduct by local chiefs [75]. Consequently, such projects suffer from the lack of transparency, accountability, and trust, as the traditional authorities in Ghana often refuse to disclose contract terms for fear that others will demand to share the benefits [75]. This self-interest of chieftaincy and traditional authority institutions has created a new political space for elite capture, and raises questions about their effectiveness of being good custodians of land in Ghana [8][75][114].

10 Note that the Yendi, Kpachaa and Alipe communities all fall under Kusawgu Traditional Area 
In the second case (Kirmminic Estates Limited, Atebubu), the chieftaincy institutions showed a clear lack of capacity to analyse the investments and use that information to negotiate appropriately with the investors. This lack of capacity of chieftaincy institutions and traditional authorities has been identified as a key concern about their ability to negotiate for the benefit of their people, especially in cases of predatory corporate behaviour from biofuel investors [7].

\subsection{Weak business planning, unfulfilled promises and unfair compensation}

In the Ghanaian context, an important driver behind the failure of jatropha projects has been the unrealistic business plans of early jatropha investments [13][75] ${ }^{11}$. Highly optimistic business plans expecting high jatropha yields eventually did not materialize, while bad management due to lack of knowledge of jatropha agronomy or local circumstances further took its toll on several jatropha projects. Three such examples include Kimminic Corporation, Savanna Black and Biofuel Africa (Table 3) discussed below.

In a recent study the manager of Kimminic Corporation (Abease area), cited reasons of economic inefficiency and limited market opportunities behind the collapse of the project [12][23]. The EIA suggests that within the first 5 years (2010-2015) Kimminic Corporation expected their estates in Abease, Bredi and Dinkra to have been able to produce 15-16 tha of jatropha seeds in full maturity [97], which is one of the highest yields reported in Africa and most likely well beyond of what can be achieved with unimproved jatropha seeds [7][38]. Expecting such large yields in a short period, the company expanded aggressively its operations. This increased quickly the operational costs without achieving immediate returns to offset them, with some people suggesting that the company was expanding the plantations more rapidly than it could manage it (Personal communication, former plantation worker of Kimminic Corporation). In this particular project, the amount paid for wages, salaries for workers and other farm investments were higher than the economic return of the project indicating very bad business planning.

In the case of Savanna Black project (Ahinakom area), some of the involved stakeholders stated that while jatropha could grow in some areas (even those described as infertile/marginal lands), oil yields were low

11 This a common theme in several of the failed jatropha projects throughout SSA [38]. This is to a large extent due to the fact that jatropha is an undomesticated crop for which little agronomical information and experience growing it commercially existed in Africa [7]. 
and could not offset the economic cost of investment (Personal communication, Security Officer of Savanna Black). Due to these poor economic returns, the initially planned investment was reduced drastically leading to the collapse of the project (Personal communication, Security Officer of Savanna Black).

Bad planning also took a toll on the Smart Oil Ltd. 4,000 ha jatropha project (Kadua area). According to interviews with the farm manager, the company initially planted a jatropha variety that did not provide sufficient yields. As a result after 2 years when yields were low they uprooted the existing jatropha trees to plant a new variety. By that time, the investment was substantial but no returns were made from selling the feedstock, so the company faced financial difficulties and eventually collapsed in 2013. The company has reorganised and started operations again in 2015.

Bad planning was also evident and in BioFuel Africa's project in Yendi area. The company complained that the compensation demanded from the local communities for giving out the 40,500 ha was higher than planned (Personal communication, Lands Commission). Apart from the role that civil society and chieftaincy institutions played in the collapse of Biofuel Africa's other two operations in Alipe and Kpachaa (Section 5.2-5.3), the continuous failure of BioFuel Africa to establish its jatropha operations raises strong concerns about its capability/knowledge to run a jatropha-based business.

Weak financial planning and project management apart from having negative direct results on the operation of the jatropha projects themselves, it also resulted in unfulfilled promises from the part of the companies to the local communities [13]. Promises to local communities were usually in the form of:

(a) employment in the jatropha plantations

(b) compensation for loss of land

(c) provision of social services/infrastructure (schools, clinics, water supply).

In terms of employment generation, in several jatropha projects the high-skill and high-paid employees often tended to come from outside the affected communities [104]. In the case of the BioFuel Africa project in the Volta Region (Loilito), the promised local jobs never materialised as many of the employees are not natives of Lolito [85][91]. 
Several local communities were also poorly compensated leading to agitations and conflicts in different parts of the country [8][23][82][85][89]. For several jatropha projects in Ghana, over $85 \%$ of farmers never received the compensations promised by the jatropha companies [85][91], while the promised social services such as schools and clinic often never materialized [93].

Whilst the authenticity and legitimacy of the promises made by biofuel companies is difficult to be assessed post-collapse [92], it seems that the long awaiting for compensation by local communities and early changes in business models (e.g. feedstock changes by companies such as ScanFuel), served as sources of conflict and discontent with local communities, eventually contributing to project collapse [82]. The ensuing dissatisfaction of local communities due to such unfulfilled promises has been a major collateral blow to the viability of several biofuel projects in Ghana such as the BioFuel Africa projects in Lotilo and Kpachaa (Table 3) [12][23][76][85][89][92].

Finally a recent study that assessed the perceptions of households in relation to the introduction of jatropha in different communities, has shown that respondents believed they were worse off after the introduction of jatropha, and felt poorer than neighbouring communities despite having benefited to an extent from the generated employment [92][93].

\subsection{Role of the state and institutional barriers}

The 2006 draft biofuel policy envisioned that by 2008 biofuels would have been successfully introduced into the Ghanaian market, and that government vehicles would have formed a major component of the biofuel market (Section 2.1). The Ghanaian government was responsible for passing and implementing appropriate policies to develop a viable market in the country. However, following the collapse of the National Jatropha Project, the initial plans were less likely to materialize. Currently no state-led commercial biofuel processing is taking place in Ghana [68], and hence there is no domestic biofuel market. Although the National Petroleum Authority is mandated to fix prices for biofuel products, this is yet to be done. In this respect, the Ghanaian biofuel programme has been a failure ${ }^{12}$, and in our view the lack of implementing existing policies (Table 1) has been key to this.

\footnotetext{
12 While there was some modest biofuel production, it was nowhere near the initial expectations of high domestic biofuel mandates or export to other countries (Section 2.1). For example, Biofuel Africa produced its first 50 barrels of jatropha-based fuel in 2009 for domestic car use, before collapsing (Table 3). Dumpong Biofuels also produced 500 litres of palm oil biodiesel in 2008 for farm machinery. Some other examples include small-scale biofuel production for use in the shea industry and for rural electrification [61][74] (Section 3.1). The Smart Oil jatropha plantation in Yeji, possibly the only operational jatropha project in
} 
In our view, a second major policy-related issue that hindered the success of several biofuel projects in Ghana was the absence of clear guidelines for large-scale land acquisitions coupled with the decentralization of land administration. Discontent related to land acquisition procedures has been an underlying factor of the collapse of several jatropha projects, whether it involved foul play from chiefs (Section 5.3), agitations from NGOs (Section 5.2) or bad planning and lack of compensating local communities from companies (Section 5.4).

Ghana, much like other parts of SSA, has over the years struggled to harmonize the customary land administration system with statutory processes [110]. While this is not a biofuel-specific issue, the absence of a harmonized regulatory framework meant that illicit acquisitions became commonplace in Ghana (and across SSA) [8]. It was not until 2012 that the government of Ghana responded to this by drafting a guideline for large-scale land acquisitions [115]. However, this delay prohibited the timely resolution of land disputes between investors and communities.

Furthermore, with limited regulatory protection disputes between investors and communities were difficult to be resolved, and often put investors at a weaker position against chieftaincy institutions [73]. Such an example is the case of the projected 100,000 ha jatropha project of Galten Agro Ltd (Israel) and the chief of New Bakpa in the Volta Region. After the chief of Adidome sold land to the company, the chief of a neighbouring area (New Bakpa) called to halt the project citing that land is within his traditional area (Personal communication, Farm Manager of Galten Agro Ltd). This resulted in the jatropha project to collapse as the chief essentially halted the project due to this land dispute. In this case, if a common land registry ${ }^{13}$ existed in Ghana, then investors could easily crosscheck the legitimacy of sellers before proceeding with the land acquisition [85].

An important outcome of the lack of clear framework for large-scale acquisitions is that the majority of land acquired for feedstock production, is usually channelled through the customary system, which is seen to be weak to foreign powers [8][26][60][85]. The legal pluralism in Ghana unduly delayed the preparation of the guideline for large-scale acquisitions due to the diversity of stakeholders, as well as their different vested interests (Personal communication, National Lands Commission) (Section 6.1). By the time that the draft

Ghana, is currently exporting jatropha feedstock (not processed oil) to Burkina Faso, while the oil palm industry has shifted focus from the biofuel market, towards the cosmetic and food markets.

13 Land registry is a depository where landownerships and titles land are registered/recorded and stored. The current legal pluralism and decentralization of land administration have created different land registries making it difficult to harmonise and track changes in land ownerships and titles. 
land acquisition guidelines came into effect most jatropha FDIs had gained the access to land (sometimes through illicit means) and had already collapsed.

\subsection{Unproductive consultation of local communities during project design and implementation}

Despite the fact that rural development has been a key driver of biofuel expansion in Ghana (Section 2.1), few biofuel projects tried to actively integrate "beneficiary communities" in project design [37][116]. In our view, the limited participation of local communities in biofuel project design and implementation can be seen as both a consequence of the lack of corporate commitment to actually benefit local communities (Section 5.3), as much as a failure of formal (Section 5.5) and traditional institutions (Section 5.4).

There are numerous examples in Ghana of what we refer to as the unproductive consultation of local communities during project design and implementation, or to at least forge a broader social acceptability of jatropha [89]. Business plans to a large extent failed to integrate meaningfully the expectations of local communities [13][75] possibly due to their limited participation in project design.

For example, in the case of ScanFuel/ScanFarm in Agogo (Table 3), not all relevant stakeholders were properly involved during the land transaction. Though stool land ownership ${ }^{14}$ is practiced in the area, some portions of the land are directly owned by individual families who need to negotiate directly with investors. In this particular case, affected farmers were informed of the land deal only when negotiations had already been concluded between the chief and the investors. However, the affected farmers are usually required to address such concerns through their chief [85] amidst the limited interface between them and the investors.

The Farm Manager of ScanFuel said that "the chief has not done the right thing because if the people had been engaged, we would have had peace" [82](page 27). In other jatropha projects in the Yendi, Kadelso, Yeji and Apile, failure to reach a consensus about the necessary compensation between farmers, investors and chiefs was a major failure in the overall project design and implementation (Personal communication; Land Commission, Tamale).

\section{TOWARDS A SYNTHESIS OF THE DRIVERS OF FAILURE OF THE JATROPHA SECTOR IN GHANA}

\subsection{The role of different stakeholder in the chain of jatropha failure}

14 In these cases, land is held by a stool on behalf of (and in trust for) the subjects of the stool. This is in accordance with customary law in Ghana. 
Section 5 highlighted the numerous drivers/reasons that have contributed to the collapse of the jatropha sector in Ghana. To a large extent these are similar to the drivers/reasons cited for hindering the viability/sustainability or contributing to the collapse of other jatropha projects across Africa [6][36][38][41][50][117][118].

However, these drivers of failure are highly interlinked and rarely work independently. For example, the unrealistic business plans and the lack of investor experience with jatropha production (Section 5.4) are key reasons behind the collapse of several jatropha projects (Table 3). Yet these plans have passed through the registration processes of both the Ghana Investment Promotion Centre and the Energy Commission unscrutinised. This suggests the lack of institutional frameworks to regulate properly the biofuel sector (Section 5.5). Local communities when being confronted with unrealistic business plans (Section 5.4) gave out land expecting jobs/income/development that eventually did not materialise. Still they were not consulted properly (Section 5.6) or their interests were not considered adequately due to the unconstructive involvement of chieftaincy institutions (Section 5.3). Failures and omissions at each project stage, from the feasibility study of the investment (Section 5.4), to process for acquiring land (Section 5.5) and the local negotiations (Section 5.3) gave rise to local conflicts that were sometimes fuelled by civil society opposition (Section 5.2). Even when jatropha oil was produced it had limited domestic avenues to be sold due to the failure of existing policies to create a viable market (Section 5.5), or even the decreasing oil prices due to the discovery of crude oil (Section 5.1).

However, to fully synthesize the lessons learnt through the above literature review, it is important to put the drivers of biofuel project collapse (Section 5) into perspective of the different vested interests of the multiple actors involved in the chain of jatropha project failure in Ghana. Table 5 summarises these different roles and interests as they emerge from the academic literature, site visits and expert interviews. These different vested interests can serve as sources for potential conflict.

\section{[Table 5]}

To highlight their interaction, Figure 3 depicts the major links among these interests. It suggests that among the different actors there are two forms of interactions. The first relates on "what is on offer", and the second on "what is being expected in return" (e.g. a farmer offering land will expect compensation through money or employment Section 5.3). Table 6 summarises the most important such interactions.

\section{[Figure 4]}




\section{[Table 6]}

Table 6 suggests that issues related to land administration are central to the current state of failure in the jatropha sector. On several occasions customary and formal land rights have been abused, with many irregularities in the land acquisition process [27][82][84][101][102][109]15.

For this reason, in Figure 3 land features on several on the dotted lines, which indicates serious gaps in land administration procedures, lack of harmonization, and limited collaboration among actors related to the land system, during the development and operation of jatropha projects. In particular, the lack of a "land bank ${ }^{16 "}$ by the Lands Commission, which the companies could use to verify the legitimacy of sellers, has created space for illicit acquisition procedures [85]. For example, when land administration fails to resolve the various conflicts of interest, actors are left to devise alternative means to achieve their goals [85][92]. As a result, there have been several cases where companies dealt closely with chiefs and local communities with limited participation of national and local government institutions [73]. Some NGOs have accused these methods as harking "back to the darkest days of colonialism" [84](page 1).

Whereas the chiefs/traditional authorities often get their share of the deal with the jatropha companies because of their influence, position and power as custodians of land, the local communities are often left out of the negotiation processes and project design (Section 5.6). The motivation of chiefs in land deals has on several occasions been described as that of 'self-interest' [75], with the interests of local communities being marginalised. Land has also been a critical issue in the discontent of local communities with jatropha companies, whether because they were not consulted or compensated properly (e.g. Section 5.6). In some cases, NGOs capitalised on such discontent again bringing land as a major component of the criticism used (e.g. land-grabbing) (Section 5.2). When tensions become high, investors have no choice than to pull out.

\subsection{Emerging regional narratives of jatropha impacts and failure in Ghana}

15 This complex debate on land tenure and loss of access to land due to irregularities in the land acquisition process (often described as "land-grabbing"), is not only a feature of biofuel investments, but of practically every large-scale land acquisition in such problematic contexts [106].

16 Land Banks are quasi-governmental entities created by national or local authorities to effectively develop an inventory of all land available for future sale to prospective investors or private owners. 
Jatropha projects in Ghana have mostly concentrated in the forest and savanna regions (Figure 2). Depending on the location of the biofuel project, different impacts were usually studied, e.g. environmental impacts such as deforestation/land degradation for projects located in the rainforest zone, and food security/rural livelihoods for projects located in the savanna zone (Section 4). This suggests the emergence of two different regional narratives of failure/impact; environmental activism (e.g. deforestation in the rainforest belt) and development pessimism (e.g. food insecurity in the savanna region).

In the forest regions of Ghana, arguments against jatropha are often linked to the deforestation due to large-scale land clearance. While it is often argued that jatropha could grow on marginal lands in SSA [18][120], there are also several examples of jatropha projects that have converted forested land both in Ghana [14] and elsewhere in SSA [38]. Whereas actual peer-reviewed evidence of forest conversion into biofuel plantations in Ghana is limited [14], NGOs in Ghana have often cited deforestation and noncompliance with environmental regulations as a basis for their advocacy [82][83][84]. The environmental activism narrative in this case claims that biofuels are environmentally unsustainable and a form of greenwashing that must be abandoned [27].

In the savanna regions of Ghana, advocacy against biofuel is framed in relation to the pre-existing socioeconomic challenges of the area, such as food insecurity and poverty. While more than $80 \%$ of the population of savanna regions in Ghana are involved into agriculture, a large portion is food insecure with malnutrition, infant mortality and extreme poverty very prevalent in the area [98]. Contrary to the initial development optimism narrative that focused on the opportunities that jatropha offered to smallholders [61][120], a development pessimism narrative subsequently emerged that saw the dangers of jatropha expansion as expressed through its poor development outcomes. These dangers include the loss of livelihoods, land dispossession, rise in prices of crude oil, and the low economic returns of jatropha investments [82][83][84].

This development pessimism narrative fits well into the political ecology discourse of the emergence of environmental conflicts due to the marginalization of different groups and the uneven socio-environmental distribution of benefits and burdens. Indeed, several marginalized actors in Ghana (i.e. local communities) do think that jatropha projects had an uneven distribution of benefits between them, their local elites and the investor [12][23][70][77][78][89][91]. This echoes well with other studies in Asia and Africa that used political ecology and point out that marginalization, local conflicts and the unfulfilled promises as sources of unsustainability or even mass failure of jatropha projects [122][123][124]. 
It is worth noting that despite the widespread jatropha failure in Ghana as documented in this paper, some local communities around collapsed jatropha projects are still in favour of future jatropha investments in their area [125]. Usually this willingness to further support jatropha is observed in areas where the reasons of collapse emanated from issues related solely the company (e.g. weak business planning, low jatropha yields) and reflects some short of development optimism (i.e. expectations of employment and income) [125]. On the contrary low acceptability of future jatropha ventures is observed in areas that experienced community conflicts either due to unfulfilled promises by companies, agitation by NGOs, unconstructive involvement of chieftaincy institutions or some synergistic combinations of the above [125]. This skepticism reflects more closely the development pessimism narrative discussed above.

\section{CONCLUSIONS}

The Ghanaian biofuel programme transformed from its initial aim to promote energy security through smallholder-based projects, to its eventual aim to promote rural development through FDIs and exports to international markets. However currently Ghana's biofuel programme can be seen as a total failure considering (a) the collapse of almost every jatropha project, (b) the political indifference as evidenced by the almost complete lack of the implementation of biofuel policies, and (c) the complete lack of a domestic biofuel market or exports to other countries. These show clearly that none of the policy drivers of biofuel expansion in Ghana was met.

The failure of jatropha projects in Ghana is largely a reflection of several interrelated factors. Starting with the discovery of crude oil, the energy security purpose of biofuel expansion was defeated. This was followed by a change in the political regime, which translated, into low political commitment. This largely prohibited the development of supporting structures before the biofuel boom of the mid- to late-2000s (e.g. development of agronomic knowledge, demarcation of suitable land, reforms in the land administration system, guidelines for large-scale land acquisitions, national/local platforms for consensus building for biofuel investments). In our view such structures could have enhanced the long-term sustainability/viability of the biofuel sector.

However, it should be mentioned that no African country had such structures in place before the biofuel boom of the 2000s. While Malawi was already blending significant quantities of sugarcane ethanol in gasoline, this ethanol was sourced from two pre-existing sugarcane plantations that were operational well 
before the biofuel boom [126]. Mozambique eventually put in place such structures [127], but this was largely an outcome of the jatropha boom rather than an anticipation of it [128] $]^{17}$.

In view of the absence of these structures, there have been several documented examples of land-related conflicts, marginalization of communities, conflict of interests between different stakeholders in the jatropha sector and negative environmental impacts such as deforestation. Land tenure and dispossession have unsurprisingly been at the centre of jatropha project failure in Ghana, and have created unresolved changes in several rural socio-environmental contexts, serving as sources of conflicts.

With the mass failure of the jatropha sector, lack of political commitment and the suspicion of local communities and NGOs about the risks associated with jatropha, there are serious doubts whether deliberate attempts will be made to further expand the industry in Ghana. This is even more unlikely given that Ghana currently extends its oil activities in territories as far as the disputed waters with Cote d'Ivoire. The initial expectations that jatropha-based fuels could enhance energy security and promote rural development are therefore more contested than ever.

To reverse this situation (even if it is still politically feasible/desirable) will require at least some significant changes in national policies. As it stands, investors might also need to change focus from jatropha to other, more proven biofuel crops, such as sugarcane or oil palm.

In any case, any future efforts to re-vamp the biofuel sector in Ghana will need to learn from the past failures of the jatropha sector and other industrial crops such as cotton, which faced similar issues in the late 1960s. The main lessons learnt from this review include the need to (a) involve meaningfully local communities in biofuel project planning, (b) re-examine of the role of chiefs, (c) strengthen and make explicit land acquisition processes, (d) improve project site selection, and (e) implement the existing policy initiatives. In particular, improving the participation of local communities in project planning could improve drastically the acceptability of the project increasing its viability and avoiding local conflicts. For this, the development of stronger company-community interfaces and broadening the scope of EIAs [129] would be imperative for the better participation of local communities during the planning stages of biofuel projects.

$17 \mathrm{It}$ is worth noting that as in Ghana, eventually almost all jatropha projects in Mozambique collapsed [38][86] 


\section{ACKNOWLEDGEMENTS}

AG and AA acknowledge the financial support of the Japan Science and Technology Council (JST) through the funding of Belmont Forum project FICESSA. AA is supported by a Monbukagakusho scholarship offered by the Japanese Ministry of Education, Culture, Sports, Science and Technology (MEXT) through the Graduate Program in Sustainability Science - Global Leadership Initiative (GPSS-GLI), at the University of Tokyo. Dadson Awunyo-Vitor provided helpful comments in an earlier version of this draft.

\section{REFERENCES}

[1] International Energy Agency. Africa Energy Outlook: A focus on energy prospects in sub-Saharan Africa. World Energy Outlook Special Report, Paris, France, 2014.

[2] World Bank. Rising global interest in farmland: can it yield sustainable and equitable benefits? World Bank, Washington, D.C., USA, 2011.

[3] International Energy Agency. Energy Poverty: How to make modern energy access universal? Special early excerpt of the World Energy Outlook 2010 for the UN General Assembly on the Millennium Development Goals,, Paris, France, 2010.

[4] African Development Bank. Fuels and Opportunities for Low-carbon Development, African Development Report 2012 -Towards Green Growth in Africa.2012; p70-109.

[5] IMF. Energy Subsidy Reform in Sub-Saharan Africa Experiences and Lessons. Washington, D.C.,USA, 2013.

[6] Mitchell D. Biofuels in Africa; The International Bank for Reconstruction and Development/World Bank: Washington, DC, USA, 2011.

[7] Gasparatos A, von Maltitz GP, Johnson FX, Lee L, Mathai M, Puppim de Oliveira JA, et al. Biofuels in sub-Sahara Africa: Drivers, impacts and priority policy areas. Renew Sustain Energy Rev 2015;45:879901. doi:10.1016/j.rser.2015.02.006.

[8] German L, Schoneveld G, Mwangi E. Contemporary Processes of Large-Scale Land Acquisition in SubSaharan Africa: Legal Deficiency or Elite Capture of the Rule of Law? World Dev 2013;48:1-18. doi:10.1016/j.worlddev.2013.03.006. 
[9] De Schutter O. How not to think of land-grabbing: three critiques of large-scale investments in farmland. J Peasant Stud 2011;38:249-79. doi:10.1080/03066150.2011.559008.

[10] De Schutter $O$. The Green Rush: The global race for farmland and the rights of land users. Harvard Int. Law J. 2011; 52(2), 503-559.

[11] Gasparatos A, Lee L, Maltitz GP von, Mathai M V., Oliveira JAP de, Johnson FX, et al. Catalysing biofuel sustainability - international and national policy interventions. Environ Policy Law 2013;43:216-21.

[12] Boamah F. Imageries of the contested concepts "land grabbing" and "land transactions": Implications for biofuels investments in Ghana. Geoforum 2014;54:324-34. doi:10.1016/j.geoforum.2013.10.009.

[13] Schoneveld GC. The geographic and sectoral patterns of large-scale farmland investments in subSaharan Africa. Food Policy 2014;48:34-50. doi:10.1016/j.foodpol.2014.03.007.

[14] Schoneveld GC, German LA, Nukator E. Land-based investments for rural development? A grounded analysis of the local impacts of biofuel feedstock plantations in Ghana. Ecol. Society, 2011;16(4): 10

[15] Gerlach AC, Liu P. Resource-seeking Foreign Direct Investment in African Agriculture: A review of country case studies. FAO Commodity and Trade Policy Research Working Paper No. 31. FAO, Rome, Italy, 2010.

[16] Schoneveld GC. The governance of large-scale farmland investments in sub-Saharan Africa: A comparative analysis of the challenges for sustainability. Delft: Eburon Books, 2013.

[17] Horta Nogueira LA, Moreira JR, Schuchardt U, Goldemberg J. The rationality of biofuels. Energy Policy 2013;61:595-8. doi:10.1016/j.enpol.2013.05.112.

[18] Wendimu MA. Jatropha potential on marginal land in Ethiopia: Reality or myth? Energy Sustain Dev 2016;30:14-20. doi:10.1016/j.esd.2015.11.001.

[19] Singh K, Singh B, Verma SK, Patra DD. Jatropha curcas: A ten year story from hope to despair. Renew Sustain Energy Rev 2014;35:356-60. doi:10.1016/j.rser.2014.04.033.

[20] Baka J. What wastelands? A critique of biofuel policy discourse in South India. Geoforum 2014;54:315-23. doi:10.1016/j.geoforum.2013.08.007.

[21] Kuchler M, Linnér B-O. Challenging the food vs. fuel dilemma: Genealogical analysis of the biofuel discourse pursued by international organizations. Food Policy 2012;37:581-8. doi:10.1016/j.foodpol.2012.06.005.

[22] Gerber J-F. Conflicts over industrial tree plantations in the South: Who, how and why? Glob Environ Chang 2011;21:165-76. doi:10.1016/j.gloenvcha.2010.09.005. 

food security implications of jatropha biodiesel project in Northern Ghana, Paper presented at the International Conference on Global Land Grabbing, Future Agricultures Consortium, Sussex, UK, 2011.

[24] Cotula L, Dyer N, Vermeulen S. Fuel exclusion? The biofuel boom and the poor's access to land. International Institute for Environment and Development, London, UK, 2008.

[25] Cotula L, Vermeulen S, Leonard R, Keeley J. Land grab or development opportunity? Agricultural investment and international land deals in Africa. London and Rome: IIED, FAO and IFAD, 2009.

[26] Jumbe CBL, Msiska FBM, Madjera M. Biofuels development in Sub-Saharan Africa: Are the policies conducive? Energy Policy 2009;37:4980-6. doi:10.1016/j.enpol.2009.06.064.

[27] Shattuck A. The agrofuels Trojan Horse: biotechnology and the corporate domination of agriculture. In: Richard Jonasse ed. Agrofuels in the Americas. A Food First Book. Oakland: Institute for Food Dev Policy, 2009;89-101.

[28] Månsson A, Sanches-Pereira A, Hermann S. Biofuels for road transport: Analysing evolving supply chains in Sweden from an energy security perspective. Appl Energy 2014;123:349-57. doi:10.1016/j.apenergy.2014.01.098.

[29] Gunatilake H, Roland-Holst D, Sugiyarto G. Energy security for India: Biofuels, energy efficiency and food productivity. Energy Policy 2014;65:761-7. doi:10.1016/j.enpol.2013.10.050.

[30] Wianwiwat S, Asafu-Adjaye J. Is there a role for biofuels in promoting energy self sufficiency and security? A CGE analysis of biofuel policy in Thailand. Energy Policy 2013;55:543-55. doi:10.1016/j.enpol.2012.12.054.

[31] Hunsberger C, Bolwig S, Corbera E, Creutzig F. Livelihood impacts of biofuel crop production: Implications for governance. Geoforum 2014;54:248-60. doi:10.1016/j.geoforum.2013.09.022.

[32] Gasparatos A, Lee LY, von Maltitz GP, Mathai MV, Puppim de Oliveira JA, Willis KJ. Biofuels in Africa: impacts on ecosystem services, biodiversity and human wellbeing. Yokohama: United Nations University Institute of Advanced Studies, Japan, 2012.

[33] Goldemberg J, Coelho ST, Guardabassi P. The sustainability of ethanol production from sugarcane. Energy Policy 2008;36:2086-97. doi:10.1016/j.enpol.2008.02.028.

[34] Macedo IC, Seabra JEA, Silva JEAR. Green house gases emissions in the production and use of ethanol from sugarcane in Brazil: The 2005/2006 averages and a prediction for 2020. Biomass and Bioenergy 2008;32:582-95. doi:10.1016/j.biombioe.2007.12.006.

[35] OECD. Biofuels Support Policies: An Economic Assessment. Organisation for Economic Cooperation and Development (OECD). Paris, France, 2008. 
[36] Romijn H, Heijnen S, Colthoff J, de Jong B, van Eijck J. Economic and Social Sustainability Performance of Jatropha Projects: Results from Field Surveys in Mozambique, Tanzania and Mali. Sustainability 2014;6:6203-35. doi:10.3390/su6096203.

[37] Hashim N. How Knowledge, Policy Planning, and Implementation Succeed or Fail: The Jatropha Projects in Tanzania. J African Bus 2014;15:169-83. doi:10.1080/15228916.2014.956640.

[38] von Maltitz G, Gasparatos A, Fabricius C. The Rise, Fall and Potential Resilience Benefits of Jatropha in Southern Africa. Sustainability 2014;6:3615-43. doi:10.3390/su6063615.

[39] Kant P, Wu S. The extraordinary collapse of Jatropha as a global biofuel. Environ Sci Technol 2011;45:7114-5. doi:10.1021/es201943v.

[40] Habib-Mintz N. Biofuel investment in Tanzania: Omissions in implementation. Energy Policy 2010;38:3985-97. doi:10.1016/j.enpol.2010.03.023.

[41] van Eijck J, Romijn H, Smeets E, Bailis R, Rooijakkers M, Hooijkaas N, et al. Comparative analysis of key socio-economic and environmental impacts of smallholder and plantation based jatropha biofuel production systems in Tanzania. Biomass and Bioenergy 2014;61:25-45. doi:10.1016/j.biombioe.2013.10.005.

[42] Antwi E, Bensah EC, Quansah DA, Arthur R, Ahiekpor J. Ghana's biofuels policy: challenges and the way forward. Int. J. Energy Envir. 2010;1(5),805-814.

[43] Favretto N, Stringer LC, Dougill AJ. Policy and institutional frameworks for the promotion of sustainable biofuels in Mali. Centre for Climate Change Economics \& Policy Working Paper No. 103. London and Leeds, 2012.

[44] Oshewolo S. Designed to fail? Nigeria's quest for biofuel. Afro Asian J. Social Scie. 2012;2(3.3), 1-15.

[45] Yusuf SA.The Biofuel Energy Alternative.West Africa Insight. January: 2013 Crude Refining, 2013. Available online at: http://www.westafricainsight.org/articles/PDF/225 (Accessed on 04/04/2015).

[46] Ohimain El. Can the Nigerian biofuel policy and incentives (2007) transform Nigeria into a biofuel economy? Energy Policy 2013;54:352-9. doi:10.1016/j.enpol.2012.11.051.

[47] Abila N. Biofuels development and adoption in Nigeria: Synthesis of drivers, incentives and enablers. Energy Policy 2012;43:387-95. doi:10.1016/j.enpol.2012.01.019.

[48] Anseeuw W, Lay J, Messerli P, Giger M, Taylor M. Creating a public tool to assess and promote transparency in global land deals: the experience of the Land Matrix. J Peasant Stud 2013;40:521-30. doi:10.1080/03066150.2013.803071.

[49] Anseeuw W. BM. BT. GM. LJ. MP. NK. Transnational land deals for agriculture in the global south : analytical report based on the Land Matrix database n.d. 2012. 
[50] van Eijck J, Romijn H, Balkema A, Faaij A. Global experience with jatropha cultivation for bioenergy: An assessment of socio-economic and environmental aspects. Renew Sustain Energy Rev 2014;32:86989. doi:10.1016/j.rser.2014.01.028.

[51] Achten WMJ, Trabucco A, Maes WH, Verchot LV, Aerts R, Mathijs E, et al. Global greenhouse gas implications of land conversion to biofuel crop cultivation in arid and semi-arid lands - Lessons learned from Jatropha. J Arid Environ 2013;98:135-45. doi:10.1016/j.jaridenv.2012.06.015.

[52] ECOWAS. ECOWAS Energy Protocol, enacted 2003-01-31 at Dakar, 2003. http://www.jus.uio.no/english/services/library/treaties/09/9-02/ecowas_energy_protocol.xml (accessed on 20/05/2015).

[53] Energy Commission. Strategic National Energy Plan 2006 - 2020, Ghana, Accra, 2006.

[54] Nigerian National Petroleum Corporation. Official Gazette of the National Biofuels Policy and Incentives.Government of the Federal Republic of Nigeria, 2007.

[55] Ministry of Mines, Energy and Water. National Strategy for Biofuel Development, Mali. Available, 2007. from:http://anadeb-mali.org/

[56] ECOWAS Centre for Renewable Energy and Energy Efficiency. ECOWAS Renewable Energy Policy.Adopted by the ECOWAS Ministers at the ECOWAS High Level Energy Forum, 29 to 31 October 2012, Accra, Ghana.

[57] REN21.Renewables 2015: Global Status Report. Paris: REN21 Secretariat;2015.

[58] Brew-Hammond A.Bioenergy for Accelerated Agro-Industrial Development in Ghana. Keynote Address delivered on behalf of Ghana Energy Minister for Energy at the Bioenergy Markets West Africa Conference, Accra, 2009.

[59] Energy Commission. Ghana Bio-fuels Policy. Policy Recommendations. Final Draft, 2005, Accra, Ghana, 2005.

[60] Ahmed A, Kanton S, Godwin K., Rahim AA., Salia RA. Biofuel development and large scale land acquisitions in Ghana, implications for land use planning. Int. J. Dev Res, 2014;4(12):2563-2571.

[61] UNDESA. Small-Scale Production and Use of Liquid Biofuels in Sub-Saharan Africa: Perspectives for Sustainable Development. 15th Session on Commission on Sustainable Development, 30 April-11 May, 2007. New York, 2007.

[62] Favretto N. Powering Mali with sustainable biofuels? Livelihood opportunities and policy challenges of Jatropha curcas. Thesis Submitted in accordance with the requirements for the degree of Doctor of Philosophy. University of Leeds, School of Earth and Environment, 2014. 
[63] Bouffaron P, Castagno F, Herold S. Straight vegetable oil from Jatropha curcas L. for rural electrification in Mali - A techno-economic assessment. Biomass and Bioenergy 2012;37:298-308. doi:10.1016/j.biombioe.2011.11.008.

[64] Energy Commission. Draft Bioenergy Policy of Ghana. Accra, Ghana, 2010.

[65] EC. Directive 2009/28/EC on the Promotion of the Use of Energy from Renewable Sources.Official Journal of the European Union, L140 2009;16-62.

[66] Energy Commission. Licence Manual for Service Providers in the Renewable Energy Sector Industry, 2012. Available online http://www.energycom.gov.gh/files/RE\%20LICENCE\%20MANUAL.pdf

[67] Energy Commission. Renewable Energy Act. Ghana, Accra, 2011.

[68] Iddrisu I, Bhattacharyya SC. Ghana's bioenergy policy: Is $20 \%$ biofuel integration achievable by 2030 ? Renew Sustain Energy Rev 2015;43:32-9. doi:10.1016/j.rser.2014.10.066.

[69] Ministry of Trade and Industry. Draft national sugarcane policy, Accra, Ghana, 2015.

[70] Boamah F, Overå R. Rethinking Livelihood Impacts of Biofuel Land Deals in Ghana. Dev Change 2015:n/a - n/a. doi:10.1111/dech.12213.

[71] Boamah, F. Competition between Biofuel and Food? Evidence from Ajatropha Biodiesel Project in Northern Ghana, in P. Matondi, K. Havnevik and A. Beyene (eds) Biofuels, Land Grabbing and Food Security in Africa, 2011, pp. 159-75. London: Zed Books.

[72] Kidido JK, Kuusaana ED. Large-Scale Investment in Biofuel Feedstock Production and Emerging Land Issues in Ghana. J Soc Sci Stud 2014;1:163. doi:10.5296/jsss.v1i2.5114.

[73] Kwoyiga L. Institutional analysis of biofuel production in Northern Ghana: Biofuel Africa Limited as a casestudy. A Master thesis submitted to the Department of of International Environment and Development, Norwegian University of Life Science, 2012.

[74] Karlsson G, Banda K. Biofuels for sustainable rural development and empowerment of women: case studies for Africa and Asia. ENERGIA, Leusden, The Netherlands, 2009.

[75] Schoneveld GC, German L. Translating Legal Rights into Tenure Security: Lessons from the New Commercial Pressures on Land in Ghana. J Dev Stud 2014;50:187-203. doi:10.1080/00220388.2013.858129.

[76] Boamah F. How and why chiefs formalise land use in recent times: the politics of land dispossession through biofuels investments in Ghana. Rev Afr Polit Econ 2014;41:406-23. doi:10.1080/03056244.2014.901947. 
[77] Boamah, F. Competition between biofuel and food?The case of a jatropha biodiesel project and its effects on food security in the affected communities in Northern Ghana. Master's Thesis, University of Bergen, UiB, 2010.

[78] Boamah, F. The paradox of global discourses and Ghana's biofuel debate: Evidence from biofuel investments in Northern Ghana ". A paper presented at the Agrarian and Rural Development in Africa: Stakeholder's Conference in Harare, Zimbabwe between 24th and $26^{\text {th }}$ November 2010

[79] Schoneveld GC, German LA, Nukator E. Towards Sustainable Biofuel Development: Assessing the Local Impacts of Large-Scale Foreign Land Acquisitions in Ghana. Paper summary. World Bank Land Governance Conference, 2010.

[80] Schoneveld GC. The anatomy of large-scale farmland acquisitions in sub-Saharan Africa. Working Paper No. 85. Bogor, Indonesia: Center for International Forestry Research, 2011.

[81] Land Matrix. Ghana Country target details, 2015. Available at:http://www.landmatrix.org/en/get-thedetail/by-target-country/ghana/?order_by= (accessed on 20/05/2015).

[82] ActionAid Ghana. Report on rapid appraisal on land grabbing, biofuel investments and traditional authorities in Ghana, June, 2012.

[83] ActionAid Ghana. Land grabbing, biofuel investment and traditional authorities in Ghana: Policy brief. 2012 Available at: http://www.actionaid.org/sites/files/actionaid/policy_brief.pdf

[84] Nyari B. Biofuel land grabbing in Northern Ghana. Regional Advisory and Information Network Systems, Ghana and African Biodiversity Network, 2008.

[85] Campion B, Acheampong E. The Chieftaincy Institution in Ghana: Causers and Arbitrators of Conflicts in Industrial Jatropha Investments. Sustainability 2014;6:6332-50. doi:10.3390/su6096332.

[86] Locke A, Henley G. Scoping report on biofuel projects in five developing countries. Overseas Development Institute (ODI), London, 2013.

[87] Maes WH, Trabucco A, Achten WMJ, Muys B. Climatic growing conditions of Jatropha curcas L. Biomass and Bioenergy 2009;33:1481-5. doi:10.1016/j.biombioe.2009.06.001.

[88] German L, Schoneveld G, et al. The local social and environmental impacts of biofuel feedstock expansion: A synthesis of case studies from Asia, Africa and Latin America. Working Paper No. 34. Bogor, Indonesia: Center for International Forestry Research, 2010.

[89] Acheampong E, Campion B. Socio-economic impact of biofuel feedstock production on local livelihoods in Ghana. Ghana J Geogr 2014;5:1-16. 
[90] Danso W. Land grabbing for jatropha bio-fuel in Ghana: assessing the impact on households' livelihood in northern Ghana; 2015.

[91] Acheampong E, Campion B. The Effects of Biofuel Feedstock Production on Farmers' Livelihoods in Ghana: The Case of Jatropha curcas. Sustainability 2014;6:4587-607. doi:10.3390/su6074587.

[92] Campion B, Essel G, Acheampong E. Natural resources conflicts and the biofuel industry: implications and proposals for Ghana. Ghana J Geogr 2014;4:42-64.

[93] Timko J, Amsalu A, Acheampong E, Teferi M. Local Perceptions about the Effects of Jatropha (Jatropha curcas) and Castor (Ricinus communis) Plantations on Households in Ghana and Ethiopia. Sustainability 2014;6:7224-41. doi:10.3390/su6107224.

[94] Achten WMJ, Verchot LV. Implications of biodiesel-induced land-use changes for $\mathrm{CO} 2$ emissions: case studies in tropical America, Africa, and Southeast Asia. Ecol. Socie, 2011;16(4): 14.

[95] Adanes Consult. Final Environmental Impact Assessment: proposed jatropha farm project, Adidome. Ghana, Accra, 20111.

[96] Centre for Environment and Health Research and Training. Final Environmental Impact Assessment: proposed jatropha farm project, Kpachaa. Ghana, Accra, 2010.

[97] Centre for Environment and Health Research and Training. Final Environmental Impact Assessment: proposed jatropha farm project, Kobre. Ghana, Accra, 2010.

[98] Nyantakyi-Frimpong $\mathrm{H}$, Bezner-Kerr R. The relative importance of climate change in the context of multiple stressors in semi-arid Ghana. Glob Environ Chang 2015;32:40-56. doi:10.1016/j.gloenvcha.2015.03.003.

[99] Lawson IYD, Adiku SGK, Danso SKA.The Petroleum Find: Its Possible Impact on the Agricultural Sector in Ghana: The Role of Soil Science. West African J. of Appl. Ecol. 2014; 22(2), 45-55.

[100] FACT Foundation. FACT Position Paper Food Fuels, 2009. Available at: http://factfoundation.com/sites/default/files/library/documents/56._fact_position_paper_food_fuels.pdf (accessed on 20/05/2015)

[101] Oxfam International. Another Inconvenient Truth: How Biofuel Policies are Deepening Poverty and Accelerating Climate Change, Oxfam Briefing Paper, June, 2008.

[102] Oxfam International. Our land, our lives, time out on the global land rush. Oxfam International briefing note, October, 2012.

[103] Friends of the Earth (FoE). Africa: up for grabs - the scale and impact of land grabbing for agrofuels. Friends of the Earth, Brussels, Belgium, 2010. 
[104] Friends of the Earth International. Jatropha: money doesn't grow on trees: ten reasons why jatropha is neither a profitable nor sustainable investment. Issue 120. Amsterdam, the Netherlands, 2010.

[105] Thompson P. The Agricultural Ethics of Biofuels: The Food vs. Fuel Debate. Agriculture 2012;2:33958. doi:10.3390/agriculture2040339.

[106] Allan JA, Keulertz M, Sojamo S, Warner J, (Eds). Handbook of Land and Water Grabs in Africa: Foreign direct investments and food and water security. Routledge London, 2013.

[107] Matondi P, Håvnevik K, Beyene A, (Eds). Biofuels, land grabbing and food security in Africa. Africa Now Series, Zed Books, London, 2011.

[108] Wiggins S, Henley G, Keats S. Competitive or complementary? Industrial crops and food security in sub-Saharan Africa. Overseas Development Institute (ODI), London, 2014.

[109] White B, Dasgupta A. Agrofuels capitalism: a view from political economy. J Peasant Stud 2010;37:593-607. doi:10.1080/03066150.2010.512449.

[110] Lentz C. Decentralization, the State and Conflicts over Local Boundaries in Northern Ghana. Dev Change 2006;37:901-19. doi:10.1111/j.1467-7660.2006.00506.x.

[111] Deininger K. Land policies for growth and poverty reduction (World Bank Research Policy Report). Washington, DC: World Bank, 2003.

[112] Kasanga K. Land tenure, resources access, and decentralization in Ghana. In C. Toulmin, P. LavigneDelville, \& S. Traoré (Eds.), The dynamics of resource tenure in West Africa. Ann Harbor, Ml: University of Michigan, 2009.

[113] Crook RC. Access to Justice and Land Disputes in Ghana's State Courts: The Litigants' Perspective. J Leg Plur Unoff Law 2004;36:1-28. doi:10.1080/07329113.2004.10756576.

[114] Yaro JA. Re-inventing traditional land tenure in the era of land commoditization: some consequences in periurban northern Ghana. Geogr Ann Ser B, Hum Geogr 2012;94:351-68. doi:10.1111/geob.12003.

[115] Lands Commission. Guidelines for Considering Large-Scale Land Transactions for Agricultural and other Purposes. Accra, Ghana, 2012.

[116] Romijn HA, Caniëls MCJ. The Jatropha biofuels sector in Tanzania 2005-2009: Evolution towards sustainability? Res Policy 2011;40:618-36. doi:10.1016/j.respol.2011.01.005.

[117] Van Eijck J, Smeets E, Jongschaap R, Romijn H, Balkema A. Jatropha Assessment: Agronomy, Socio-Economic Issues and Ecology, Facts from Literature; Utrecht University, Copernicus Institute: Utrecht, The Netherlands, 2010. 
[118] Hofmann M, Khatun K. Facilitating the financing of bioenergy projects in sub-Saharan Africa. Energy Policy 2013;52:373-84. doi:10.1016/j.enpol.2012.09.047.

[119] Celestino CP. Curse or Cure-all? The expansion of biofuels in Ghana and its effects on the right to land and food security, Madrid: Universidad Carlos III, 2010.

[120] Kesava Rao AVR, Wani SP, Singh P, Srinivas K, Srinivasa Rao C. Water requirement and use by Jatropha curcas in a semi-arid tropical location. Biomass and Bioenergy 2012;39:175-81. doi:10.1016/j.biombioe.2012.01.013.

[121] IFAD-FAO. Jatropha: A smallholder energy crop: The potential for pro-poor development. Rome, 2010.

[122] Ariza-Montobbio P, Lele S, Kallis G, Martinez-Alier J. The political ecology of Jatropha plantations for biodiesel in Tamil Nadu, India. J Peasant Stud 2010;37:875-97. doi:10.1080/03066150.2010.512462.

[123] Duvenage I, Langston C, Stringer LC, Dunstan K. Grappling with biofuels in Zimbabwe: depriving or sustaining societal and environmental integrity? J Clean Prod 2013;42:132-40. doi:10.1016/j.jclepro.2012.11.011.

[124] Duvenage I, Taplin R, Stringer L. Bioenergy project appraisal in sub-Saharan Africa: Sustainability barriers and opportunities in Zambia. Nat Resour Forum 2012;36:167-80. doi:10.1111/j.14778947.2012.01453.x.

[125] Ahmed A., Campion BB, Gasparatos A. Towards a classification of drivers of jatropha collapse in Ghana: is there still a future for jatropha-based biofuel in Africa? Journal of Rural Studies (under review)

[126] Johnson FX, Silveira S. Pioneer countries in the transition to alternative transport fuels: Comparison of ethanol programmes and policies in Brazil, Malawi and Sweden. Environ Innov Societ Trans 2014;11:124

[127] Schut M, Cunha Soares N, van den Gen G, Slingerland M. Multi-actor governance of sustainable biofuels in developing countries. Energy Policy 2014a;65: 631-43.

[128] Slingerland M, Schut M. Jatropha developments in Mozambique: Analysis of structural conditions influencing niche-regime interactions. Sustainability 2014;11:7541-63.

[129] A. Ahmed, A. Gasparatos, A. Rapid sustainability appraisal of collapsed jatropha projects in Ghana using local community perceptions: Methodological implications for sustainability science, in Esteban, M., Akiyama, T., Chiahsin, C., Ikeda, I. (Eds.), Sustainability Science: Field Methods and Exercises. (2016) Springer, Berlin. 


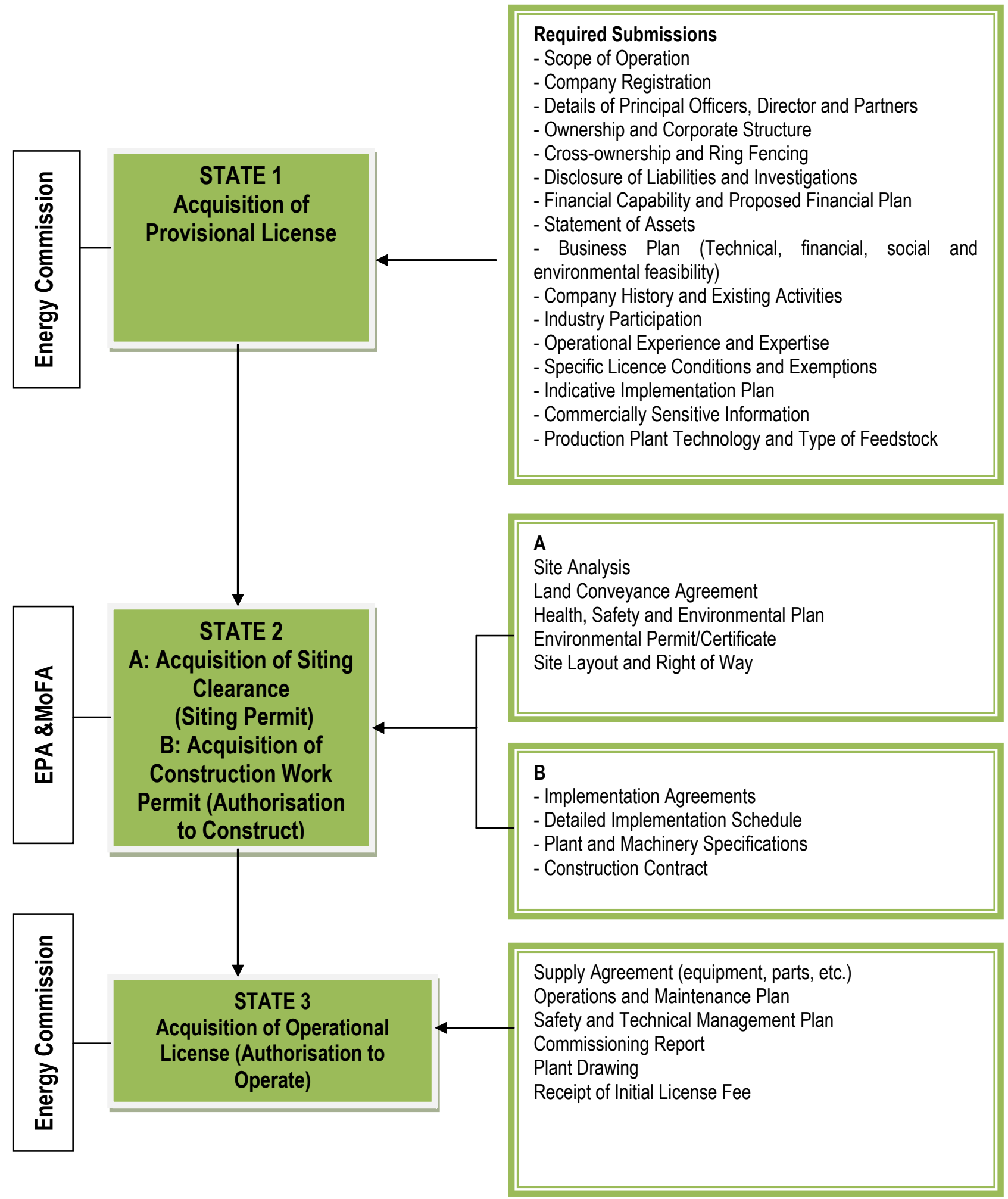

Figure 1: Formal steps for acquiring a feedstock/biofuel production license in Ghana. Source:

Adapted from [66] 


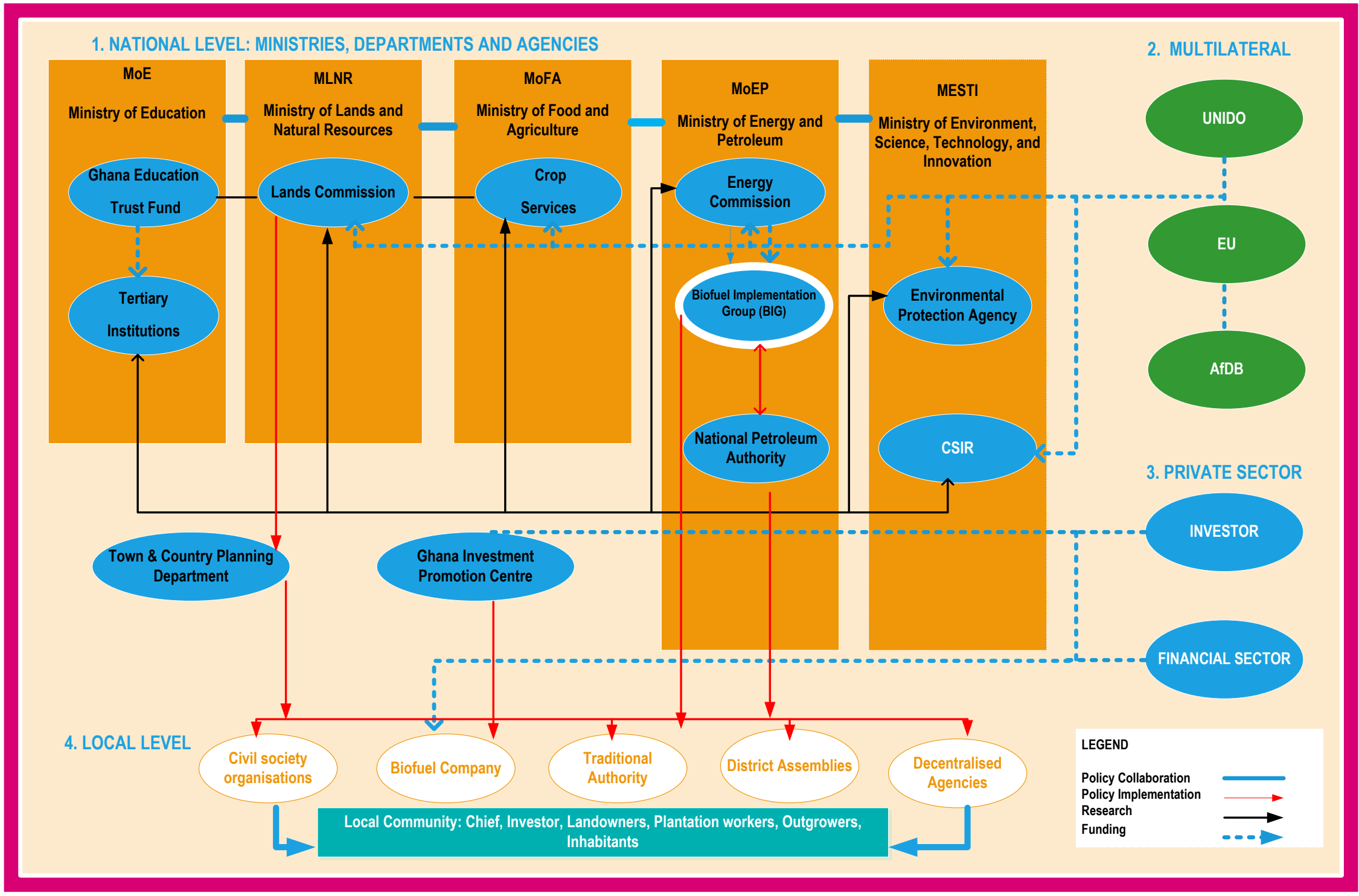

Figure 2: Institutional mapping and interlinkages of the main actors involved in biofuel promotion in Ghana 


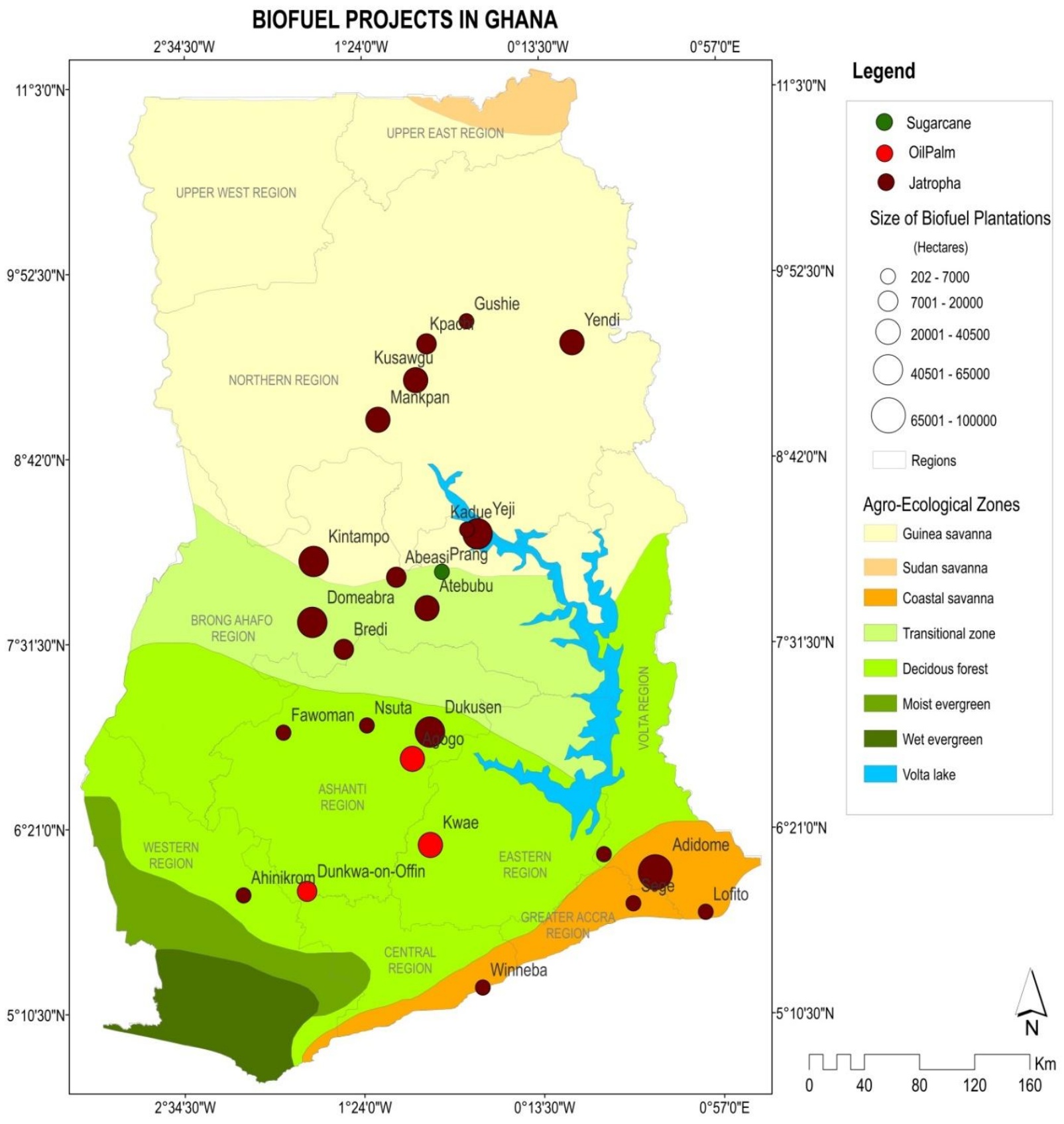

Figure 3: Location and sizes of large-scale biofuel projects in Ghana 


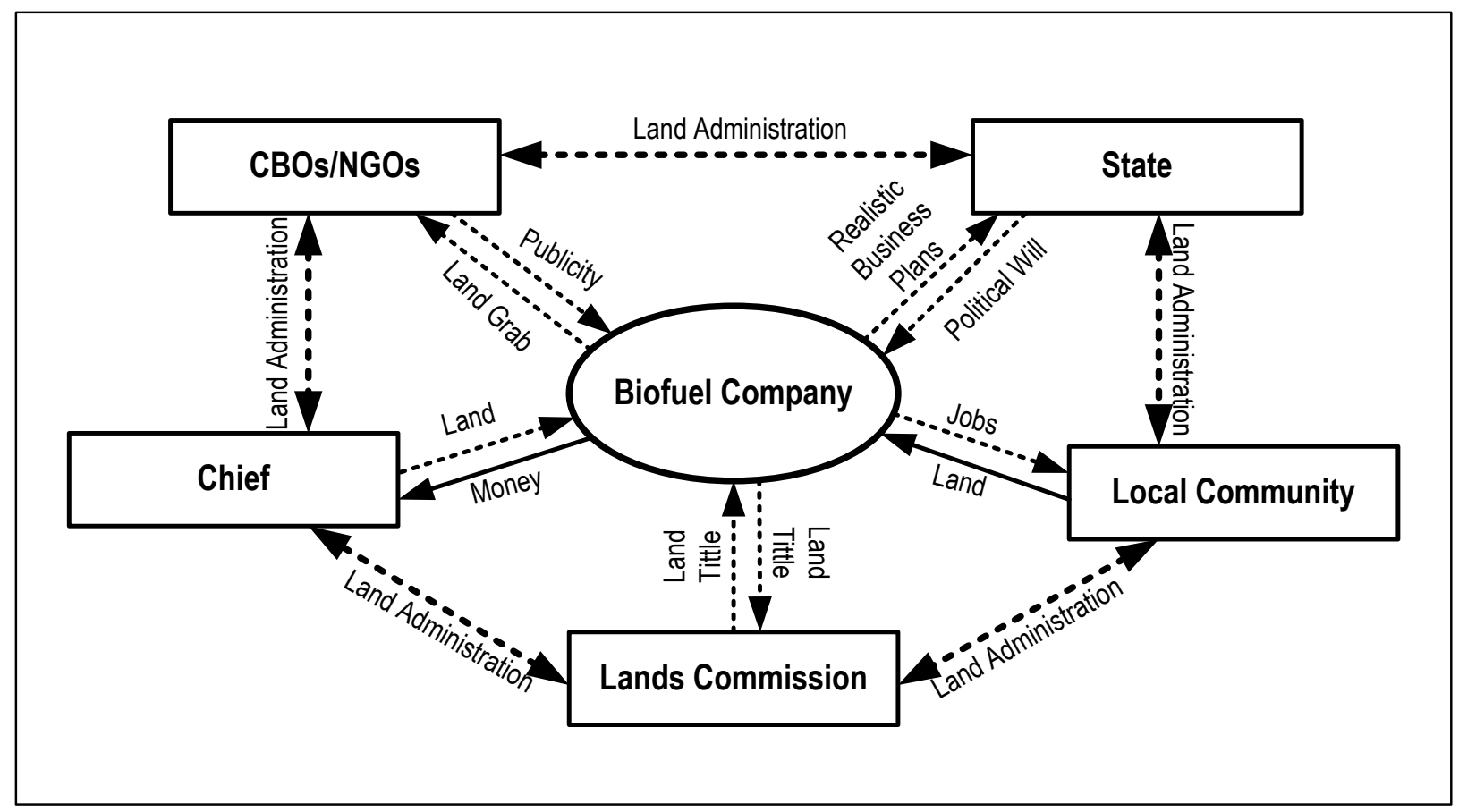

Note: Dotted lines depict expectations between that were not met as suggested by the cited literature, site visits and expert interviews.

Figure 4: Conceptual framework of linkages of drivers of failure 
Table 1: Key biofuel initiatives in Ghana

\begin{tabular}{|c|c|c|c|c|c|}
\hline \multirow[t]{2}{*}{ Activity } & \multirow{2}{*}{$\begin{array}{l}\text { Year } \\
\text { Started }\end{array}$} & \multirow{2}{*}{$\begin{array}{l}\text { Year } \\
\text { Ended }\end{array}$} & \multirow[t]{2}{*}{ Institutional responsibility } & \multicolumn{2}{|c|}{ Implementation } \\
\hline & & & & Yes & No \\
\hline Set up national committees for Gasohol and Biodiesel & 2006 & 2007 & - Energy Commission & $\checkmark$ & \\
\hline $\begin{array}{l}\text { Encourage cultivation of jatropha (for biodiesel production) and } \\
\text { sugarcane/cassava (for alcohol production) }\end{array}$ & & & $\begin{array}{l}\text { - Private sector } \\
\text { - Ministry of Food and Agriculture } \\
\text { - Energy Commission } \\
\end{array}$ & $\checkmark$ & \\
\hline Commission a commercial biodiesel plant & & & - Private sector & & $x$ \\
\hline Develop regulations for gasohol and biodiesel as transport fuel & & & $\begin{array}{l}\text { - Energy Commission } \\
\text { - National Petroleum Authority (NPA) }\end{array}$ & $\checkmark$ & \\
\hline $\begin{array}{l}\text { Attempts to re-activate the Komenda and the Asutuare sugar } \\
\text { factories }\end{array}$ & 2008 & $2010^{*}$ & $\begin{array}{ll}\text { Joint } \\
\text { initiative }\end{array}$ & & $x$ \\
\hline $\begin{array}{l}\text { Install gasohol and biodiesel blending plants in Tema and } \\
\text { Takoradi }\end{array}$ & & 2010 & $\begin{array}{l}\text { - Energy Commission } \\
\text { - National Petroleum Authority (NPA) }\end{array}$ & & $x$ \\
\hline $\begin{array}{l}\text { Introduce B5 and E10 blends in the national transport fuel } \\
\text { market }\end{array}$ & & 2015 & $\begin{array}{l}\text { - Oil Marketing Companies (OMCs) } \\
\text { - Bulk Oil Storage \& Transportation Co. }\end{array}$ & & $x$ \\
\hline Install gasohol and biodiesel blending plants in Kumasi & 2009 & 2012 & Ltd (BOST) & & $x$ \\
\hline $\begin{array}{l}\text { Introduce B10 and E20 with voluntary participation by Oil Market } \\
\text { Companies (OMCs) }\end{array}$ & & 2010 & & & $x$ \\
\hline Install biodiesel blending plants in Tamale and Bolgatanga & & 2012 & & & $x$ \\
\hline Install gasohol blending plants in Komenda and Asutuare & 2013 & 2020 & & & $x$ \\
\hline Introduce gasohol blends of up to E85 & & 2020 & & - & - \\
\hline $\begin{array}{l}\text { Make B5, B10 and E10 blends mandatory for dispensation at all } \\
\text { service stations. } \\
\text { Introduce voluntary blends of up to E85 throughout the country. }\end{array}$ & & 2020 & & - & - \\
\hline
\end{tabular}

Introduce voluntary blends of up to E85 throughout the country.

${ }^{*}$ As of May 2016, only the Komenda sugar factory has been revived (partially and behind schedule)

Source: Adapted from [53] 
Table 2: Major actors and their roles in the biofuel sector in Ghana

\begin{tabular}{|c|c|c|}
\hline Activities & Institution & Role \\
\hline Upstream & $\begin{array}{l}\text { Energy Commission (EC) } \\
\text { Environmental Protection Agency (EPA) } \\
\text { Ministry of Food and Agriculture (MoFA) }\end{array}$ & $\begin{array}{l}\text { Licensing biofuel production and exports } \\
\text { Issue permits for biofuel feedstock cultivation } \\
\text { Monitoring and supervising feedstock cultivation }\end{array}$ \\
\hline Downstream & National Petroleum Agency (NPA) & $\begin{array}{l}\text { Licensing refineries, transporters, distributors and retailers. Consumer protection } \\
\text { issues and pricing }\end{array}$ \\
\hline Others & $\begin{array}{l}\text { Ghana Standards Board } \\
\text { Bulk Oil Storage and Transportation (BOST) } \\
\text { Tertiary Educational Institutions } \\
\text { Private sector }\end{array}$ & $\begin{array}{l}\text { Product quality standards and certification } \\
\text { Establish facilities for strategic stocks and bulk storage of biofuels } \\
\text { Research and development with annual funding from the Ghana Education Trust } \\
\text { Fund for Human resource development } \\
\text { Feedstock production and refinery }\end{array}$ \\
\hline
\end{tabular}

Source: [64] 
Table 3: Characteristics of biofuel projects in Ghana

\begin{tabular}{|c|c|c|c|c|c|c|c|c|c|}
\hline REGION & LOCATION & $\begin{array}{l}\text { ACQUIRING } \\
\text { BODYIORIGIN }\end{array}$ & $\begin{array}{l}\text { FEEDSTOCK } \\
\mathrm{a}\end{array}$ & YEAR & $\begin{array}{l}\text { AREA } \\
\text { ACQUIRED (ha) }\end{array}$ & $\begin{array}{l}\text { AREA } \\
\text { PLANTED (ha) }\end{array}$ & $\begin{array}{l}\text { PRODUCTION } \\
\text { STATUS }\end{array}$ & REASON FOR COLLAPSE & SOURCE \\
\hline \multirow{2}{*}{$\begin{array}{l}\text { Ashanti } \\
\text { region }\end{array}$} & Agogo & $\begin{array}{l}\text { Scanfuel (Now } \\
\text { ScanfarmGh Ltd) } \\
\text { Norway }\end{array}$ & Jatropha/Maize & 2007 & $\begin{array}{l}47,000 \text { (Chief) } \\
13,000 \text { (Investor) } \\
32,566 \text { (LC) }\end{array}$ & 1,050 & $\begin{array}{l}\text { Jatropha } \\
\text { collapsed } \\
\text { (700 ha) } \\
\text { Maize ongoing }\end{array}$ & $\begin{array}{l}\text { The low perceived economic } \\
\text { efficiency of jatropha, } \\
\text { especially after crude oil } \\
\text { discovery }\end{array}$ & [82] \\
\hline & Nsuta,Sekyere & $\begin{array}{l}\text { Hazel Mercantile } \\
\text { Ltd. (India) }\end{array}$ & Jatropha & 2011 & 4360 & 4360 & Collapsed & Not known & $\begin{array}{l}\text { Personal } \\
\text { communication, } \\
\text { Lands } \\
\text { Commission }\end{array}$ \\
\hline $\begin{array}{l}\text { Greater } \\
\text { Accra }\end{array}$ & Sege & Bionic Group (USA) & Jatropha & 2009 & 1750 & 150 & Collapsed & Not known & $\begin{array}{l}\text { Personal } \\
\text { communication }\end{array}$ \\
\hline \multirow{6}{*}{$\begin{array}{l}\mid \\
\text { Brong } \\
\text { Ahafo }\end{array}$} & Yeji & Agroils (Italy) & Jatropha & $\mathrm{N} / \mathrm{A}$ & 15,000 & 175 & Collapsed & Financial & $\begin{array}{l}\text { Site visit by } \\
\text { author }\end{array}$ \\
\hline & $\begin{array}{l}\text { Concessions } \\
\text { a) Kadue } \\
\text { b) Makomanya } \\
\text { c) Gentydua }\end{array}$ & $\begin{array}{l}\text { Smart Oil Ghana } \\
\text { Limited (ItaltyUSA) }\end{array}$ & Jatropha & 2009 & 4000 & 450 & $\begin{array}{ll}\text { Collapsed and } \\
\text { now back into } \\
\text { operation }\end{array}$ & $\begin{array}{l}\text { Initial reason for collapse was } \\
\text { lack of funding }\end{array}$ & $\begin{array}{l}\text { Site visit by } \\
\text { author }\end{array}$ \\
\hline & $\begin{array}{l}\text { Yeji Concessions } \\
\text { a) Tokobi } \\
\text { b) Brenkente } \\
\text { c) Miawani }\end{array}$ & $\begin{array}{ll}\text { Natural } & \text { African } \\
\text { Diesel } & \text { Ghana } \\
\text { Limited } & \end{array}$ & Jatropha & 2008 & 50,000 & 1,000 & Collapsed & Not known & $\begin{array}{l}\text { Personal } \\
\text { communication, } \\
\text { Lands } \\
\text { Commission }\end{array}$ \\
\hline & Abease & \multirow[t]{3}{*}{$\begin{array}{l}\text { Kirmminic Estates } \\
\text { Limited } \\
\text { (Canada/Ghana) }\end{array}$} & Jatropha & $\mathrm{N} / \mathrm{A}$ & 15,000 & 850 & Collapsed & Not known & $\begin{array}{l}\text { Personal } \\
\text { communication, } \\
\text { Former Plantation } \\
\text { Worker }\end{array}$ \\
\hline & Dinkra & & Jatropha & 2007 & 400 & 200 & Collapsed & $\begin{array}{l}\text { Poor profit in relation to } \\
\text { investment and labour costs } \\
\text { (unrealistic plans) }\end{array}$ & {$[72][75]$} \\
\hline & Bredie & & Jatropha & 2007 & 12,140 & 6070 & Collapsed & Mismanagement & $\begin{array}{l}\text { Personal } \\
\text { communication, } \\
\text { Lands } \\
\text { commission[72] }\end{array}$ \\
\hline
\end{tabular}




\begin{tabular}{|c|c|c|c|c|c|c|c|c|c|}
\hline & Atebubu & & Jatropha & $\mathrm{N} / \mathrm{A}$ & 30,000 & 2,000 & Collapsed & $\begin{array}{l}\text { Ineffectiveness of chieftaincy } \\
\text { institutions }\end{array}$ & {$[82]$} \\
\hline & Yeji ( Kobre) & & Jatropha & 2010 & $\mathrm{~N} / \mathrm{A}$ & 450 & Collapsed & $\begin{array}{l}\text { Poor profits in relation to } \\
\text { investment and labour costs } \\
\text { (unrealistic plans) }\end{array}$ & [72][75] \\
\hline & Prang & $\mathrm{N} / \mathrm{A}$ & Sugarcane & 2008 & $\mathrm{~N} / \mathrm{A}$ & 520 & Collapsed & Not known & $\begin{array}{l}\text { Personal } \\
\text { communication, } \\
\text { Lands } \\
\text { Commission }\end{array}$ \\
\hline & Domeabra & $\begin{array}{ll}\text { Jatropha } & \text { Africa } \\
\text { (UK/Ghana) } & \end{array}$ & Jatropha & 2007 & 50,000 & 1,050 & Collapsed & Not known & $\begin{array}{l}\text { Personal } \\
\text { communication, } \\
\text { Lands } \\
\text { Commission }\end{array}$ \\
\hline & Kwanim & $\mathrm{N} / \mathrm{A}$ & $\begin{array}{l}\text { Maize/Soy } \\
\text { Bean }\end{array}$ & $\mathrm{N} / \mathrm{A}$ & 22,000 & 1,210 & Collapsed & Not known & $\begin{array}{l}\text { Personal } \\
\text { communication, } \\
\text { Lands } \\
\text { Commission }\end{array}$ \\
\hline & Ahinakom & $\begin{array}{l}\text { Savannah Black } \\
\text { Farming \& Farm } \\
\text { Mgt Ltd }\end{array}$ & Jatropha & 2006 & 202 & 121 & Collapsed & $\begin{array}{l}\text { Poor yields due to low soil } \\
\text { quality }\end{array}$ & $\begin{array}{l}\text { Site visit by } \\
\text { author }\end{array}$ \\
\hline & Kadelso & $\begin{array}{ll}\text { Jatropha } & \text { Africa } \\
\text { (UK/Ghana) } & \end{array}$ & Jatropha & 2007 & 50,000 & 202 & Collapsed & Crude oil discovery in Ghana & $\begin{array}{l}\text { Personal } \\
\text { communication } \\
\text { with Farm } \\
\text { Manager }\end{array}$ \\
\hline \multirow{2}{*}{$\begin{array}{l}\text { Central } \\
\text { Region }\end{array}$} & Dunkwa on Offin & $\begin{array}{l}\text { Buabeng Oil Palm } \\
\text { Plantation (local) }\end{array}$ & Oil Palm & 2011 & $\mathrm{~N} / \mathrm{A}$ & 8230 & Collapsed & Not known & $\begin{array}{l}\text { Personal } \\
\text { communication, } \\
\text { Lands } \\
\text { Commission }\end{array}$ \\
\hline & Weniba & $\begin{array}{l}\text { Symboil } \quad A G \\
\text { (Germany) }\end{array}$ & Jatropha & 2007 & 7000 & $\mathrm{~N} / \mathrm{A}$ & Collapsed & Not known & $\begin{array}{l}\text { Personal } \\
\text { communication, } \\
\text { Lands } \\
\text { Commission }\end{array}$ \\
\hline \multirow{3}{*}{$\begin{array}{l}\text { Eastern } \\
\text { region }\end{array}$} & Kwae & Gopdc & Oil Palm & $\mathrm{N} / \mathrm{A}$ & 35,235 & 15,075 & On-going & Not known & $\begin{array}{l}\text { Personal } \\
\text { communication, } \\
\text { Lands } \\
\text { Commission }\end{array}$ \\
\hline & Afram plains & $\begin{array}{l}\text { Viram Plantation } \\
\text { Ltd. (India) }\end{array}$ & $\begin{array}{l}\text { Oil palm/ } \\
\text { Sugarcane }\end{array}$ & 2007 & 400,000 & 60,030 & $\begin{array}{l}\text { Operational as of } \\
\text { August } 2015\end{array}$ & Not known & $\begin{array}{l}\text { Personal } \\
\text { communication, } \\
\text { Lands } \\
\text { Commission }\end{array}$ \\
\hline & Juapong & Anuanom Farms & Jatropha & 2006 & 405 & 200 & Collapsed & Death of the pioneer of & {$[12]$} \\
\hline
\end{tabular}




\begin{tabular}{|c|c|c|c|c|c|c|c|c|c|}
\hline & & & & & & & & $\begin{array}{l}\text { jatropha in Ghana and owner } \\
\text { of the company }\end{array}$ & \\
\hline \multirow{6}{*}{$\begin{array}{l}\text { Northern } \\
\text { Region }\end{array}$} & $\begin{array}{l}\text { Yendi } \\
\text { (Kusawgu } \\
\text { Traditional Area) }\end{array}$ & \multirow[t]{3}{*}{$\begin{array}{l}\text { BioFuel Africa } \\
\text { (Norway) }\end{array}$} & Jatropha & 2007 & 40,500 & 15,000 & Collapsed & $\begin{array}{l}\text { Unfulfilled promises of job in } \\
\text { relation to high expectations of } \\
\text { communities. Inefficiencies in } \\
\text { chieftaincy institutions }\end{array}$ & {$[23][77][78]$} \\
\hline & $\begin{array}{l}\text { Alipe (Kusawgu } \\
\text { Traditional Area) }\end{array}$ & & Jatropha & 2007 & 38,000 & 0 & Collapsed & $\begin{array}{l}\text { Civil society negative publicity } \\
\text { and community agitation. } \\
\text { Limited participation of } \\
\text { community in project planning. }\end{array}$ & {$[76][83][84]$} \\
\hline & $\begin{array}{l}\text { Kpachaa } \\
\text { (Kusawgu } \\
\text { Traditional Area) } \\
\end{array}$ & & Jatropha & 2007 & 10,696 & 1000 & Collapsed & $\begin{array}{l}\text { Inefficiency of chieftaincy } \\
\text { institutions through non- } \\
\text { disclosure of transactions }\end{array}$ & [76][85] \\
\hline & Makango & $\mathrm{N} / \mathrm{A}$ & Jatropha & 2008 & 28,350 & 13,000 & Collapsed & Funding cuts from the investor & $\begin{array}{l}\text { Personal } \\
\text { communication, } \\
\text { Lands } \\
\text { Commission } \\
\end{array}$ \\
\hline & Kpembi & $\begin{array}{l}\text { Northern Sugar } \\
\text { Resource (BRAZIL) }\end{array}$ & Sugarcane & 2009 & $\mathrm{~N} / \mathrm{A}$ & $\mathrm{N} / \mathrm{A}$ & $\begin{array}{l}\text { Work not yet } \\
\text { started }\end{array}$ & Not known & $\begin{array}{l}\text { Personal } \\
\text { communication, } \\
\text { Lands } \\
\text { Commission } \\
\end{array}$ \\
\hline & $\begin{array}{l}\text { Dipale, Gushie } \\
\text { and } \\
\text { Tunayilli, }\end{array}$ & $\begin{array}{l}\text { Integrated Tamale } \\
\text { Fruit Company- } \\
\text { (ITFC) }\end{array}$ & Jatropha & 2001 & 1,363 & 600 & Collapsed & Community agitation & $\begin{array}{l}\text { Kidido and } \\
\text { Kuusaana, } 2014\end{array}$ \\
\hline $\begin{array}{l}\text { Volta } \\
\text { region }\end{array}$ & Adidome & Galten Agro Ltd & Jatropha & 2008 & 100,000 & 325 & Collapsed & $\begin{array}{l}\text { The chieftaincy of a } \\
\text { neighbouring community (New } \\
\text { Bakpa) blocked project } \\
\text { development due to land } \\
\text { tenure and boundary disputes } \\
\text { with Adidome community }\end{array}$ & [72] \\
\hline & Lolito & $\begin{array}{l}\text { BioFuel Africa } \\
\text { (Norway) }\end{array}$ & Jatropha & 2006 & 2300 & $\mathrm{~N} / \mathrm{A}$ & $\begin{array}{l}\text { Collapsed and } \\
\text { now turned to rice }\end{array}$ & $\begin{array}{l}\text { Community agitation and } \\
\text { funding constraints }\end{array}$ & [72] \\
\hline
\end{tabular}

a: There are several oil palm projects in Ghana. This Table contains only those that were established for biofuel purposes, or biofuels were one of the original envisaged markets. All these projects have now shifted focus to the food industry.

Source: Compiled based on data from [82], fieldwork (September 2015) and the literature sources cited. 
Table 4: Sustainability impacts of biofuel projects in Ghana

\begin{tabular}{|c|c|c|c|}
\hline \multirow[t]{2}{*}{ Dimension } & \multirow[t]{2}{*}{ Impact } & \multicolumn{2}{|c|}{ Impacts } \\
\hline & & $\begin{array}{l}\text { Studies reporting } \\
\text { positive impacts }\end{array}$ & $\begin{array}{l}\text { Studies reporting } \\
\text { negative impacts }\end{array}$ \\
\hline \multirow[t]{5}{*}{ Environment } & Deforestation & - & {$[88]$} \\
\hline & Land use change & - & [14][23] \\
\hline & GHG emissions & - & [94] \\
\hline & Access to NTFP & - & {$[14][23][89]$} \\
\hline & Water pollution & - & [89] \\
\hline \multirow[t]{4}{*}{ Economic } & Local income & $\begin{array}{l}{[14][23][70][79][88][8} \\
9][90][91]\end{array}$ & - \\
\hline & Local employment & $\begin{array}{l}{[14][23][70][79][88][8} \\
9][90][91]\end{array}$ & - \\
\hline & $\begin{array}{l}\text { Customary } \\
\text { Livelihoods }\end{array}$ & - & [23][70][79][89][91][92 \\
\hline & Attract FDls & {$[79][90]$} & - \\
\hline \multirow[t]{5}{*}{ Social } & Land dispossession & - & $\begin{array}{l}{[12][14][23][76][79][85} \\
][88][89][91][92][93]\end{array}$ \\
\hline & Food security & - & $\begin{array}{l}{[12][14][23][71][76][77} \\
][79][88][89][91][92][9 \\
3]\end{array}$ \\
\hline & Social conflicts & - & $\begin{array}{l}{[76][85][88][89][91][85} \\
][90][93]\end{array}$ \\
\hline & Trust in chieftaincy & - & {$[79][85][89][91][93]$} \\
\hline & $\begin{array}{l}\text { Access to social } \\
\text { services }\end{array}$ & [89][91][90] & - \\
\hline
\end{tabular}


Table 5: Actors, interests and their role in jatropha project failure in Ghana

\begin{tabular}{|c|c|c|c|}
\hline Actor & Interest & Role & Sources \\
\hline $\begin{array}{l}\text { Community Based Organisations } \\
\text { (CBOs) }\end{array}$ & $\begin{array}{l}\text { Land grabbing/degradation, Food } \\
\text { Security }\end{array}$ & Negative publicity of land/food-related impacts & ][76][77][78][82][84 \\
\hline Local Communities/Farmers & $\begin{array}{l}\text { Jobs, land rights and compensation } \\
\text { for land given to jatropha projects }\end{array}$ & $\begin{array}{l}\text { Limited channels to share grievances leading } \\
\text { to agitations and protests }\end{array}$ & {$[84][93][119][85][91]$} \\
\hline Chiefs & $\begin{array}{l}\text { Community 'development', but often } \\
\text { self-interest }\end{array}$ & Non-disclosure of transactions and deals & {$[75][76][85]$} \\
\hline Investors/Biofuel Companies & $\begin{array}{l}\text { Profit from growing jatropha and } \\
\text { producing fuel }\end{array}$ & $\begin{array}{l}\text { Unrealistic business plans, bad financial } \\
\text { planning, predatory behaviour }\end{array}$ & {$[75][85][91][92]$} \\
\hline Government of Ghana & $\begin{array}{l}\text { Energy security and rural } \\
\text { development }\end{array}$ & $\begin{array}{l}\text { Passive participation, lack of regulatory } \\
\text { protection for investors, lack of political } \\
\text { commitment, lack of implementation of existing } \\
\text { policies }\end{array}$ & {$[68][75][99]$} \\
\hline Lands Commission & Land title registration & $\begin{array}{l}\text { Inability to track and register large-scale } \\
\text { acquisitions due to lack of guidelines }\end{array}$ & [12][60] \\
\hline National Consumers & Cheap and reliable fuel & $\begin{array}{l}\text { Limited patronage due to falling global fuel } \\
\text { prices and discovery of crude oil }\end{array}$ & [68] \\
\hline
\end{tabular}


Table 8: Actors expectations and observed status of interactions between actors

\begin{tabular}{|c|c|c|c|}
\hline Actor combination & Expectation & Status & Main reason \\
\hline Company-Local Community & $\begin{array}{l}\text { Company expects land and social acceptance from } \\
\text { community about the jatropha investment. } \\
\text { Local community expects jobs, compensation for land } \\
\text { allocated and potentially other social services (e.g. } \\
\text { schools, clinics, roads, water provision schemes) }\end{array}$ & $\begin{array}{l}\text { Local community gives lands but the promised jobs and } \\
\text { better income either do not materialise or materialise in } \\
\text { levels much lower than promised/expected }\end{array}$ & Weak business planning (Section 5.4) \\
\hline Company-State & $\begin{array}{l}\text { Companies expect regulatory protection of } \\
\text { investment and tax incentives from government } \\
\text { (political will), } \\
\text { The state expects companies to make meaningful } \\
\text { investments that can boost national energy security } \\
\text { and/or rural development. }\end{array}$ & $\begin{array}{l}\text { The state lost political will in supporting biofuel } \\
\text { mandates or implementing existing policies. } \\
\text { Most companies have not submit realistic plans to } \\
\text { obtain permits yet get the approval to operate }\end{array}$ & $\begin{array}{l}\text { Lack of implementation of existing policies (Section } \\
5.5 \text { ) and crude oil discovery (Section 5.1) }\end{array}$ \\
\hline Company-Lands Commission & $\begin{array}{l}\text { Both company and Lands Commission are expected } \\
\text { to facilitate the acquisition and registration of land } \\
\text { titles. }\end{array}$ & $\begin{array}{l}\text { Most companies do not use the formal process of land } \\
\text { title registration because of its cumbersome nature. }\end{array}$ & $\begin{array}{l}\text { No guideline for large-scale land acquisition during } \\
\text { the biofuel boom (Section 5.5) }\end{array}$ \\
\hline Company-Local Chiefs & $\begin{array}{l}\text { Company want chiefs to facilitate land transactions } \\
\text { and assure that local conflicts will not emerge during } \\
\text { the operation of the project. } \\
\text { Local chiefs want money or compensation for land }\end{array}$ & $\begin{array}{l}\text { Several companies gave chiefs some amount of money } \\
\text { and other benefits. There was no security of land given } \\
\text { to the company by chiefs because local community } \\
\text { members agitations }\end{array}$ & $\begin{array}{l}\text { Lack of transparency and accountability from the } \\
\text { chiefs and meaningful consultation between chiefs- } \\
\text { companies-land owners (Section } 5.3 \text { and 5.6) }\end{array}$ \\
\hline Company-CBOs/NGOs & $\begin{array}{l}\text { Most CBOs/NGOs perceive large-scale acquisitions } \\
\text { as land grabs sometimes launching aggressive } \\
\text { campaigns against them. } \\
\text { Companies want to avoid bad publicity }\end{array}$ & $\begin{array}{l}\text { CBOs/NGOs have been largely opposed to biofuel } \\
\text { development in Ghana (possibly due to the focus on } \\
\text { large plantations) giving negative publicity against } \\
\text { different biofuel projects. Companies view CBO/NGO } \\
\text { involvement suspiciously. }\end{array}$ & $\begin{array}{l}\text { CBOs/NGOs perception of the negative impacts of } \\
\text { jatropha projects on local communities (section 5.2) }\end{array}$ \\
\hline $\begin{array}{l}\text { CBOs/NGOs-Chiefs-Land } \\
\text { Commission-State-Local } \\
\text { communities }\end{array}$ & $\begin{array}{l}\text { All actors expect a just and responsive land } \\
\text { administration system because land is central to } \\
\text { biofuel production }\end{array}$ & $\begin{array}{l}\text { The land administration system is currently weak and } \\
\text { fragmented. It is a major reason catalysing conflicts in } \\
\text { the jatropha chain between the different actors }\end{array}$ & $\begin{array}{l}\text { Gaps and fragmentation of land administration } \\
\text { system (section 5.5). }\end{array}$ \\
\hline
\end{tabular}

